\title{
Efficient and versatile COMU-mediated solid-phase submonomer synthesis of arylopeptoids (oligomeric $\mathrm{N}$-substituted aminomethyl benzamides)
}

Hjelmgaard, Thomas; Faure, Sophie; Stærk, Dan; Taillefumier, Claude; Nielsen, John

Published in:

Organic \& Biomolecular Chemistry

DOI:

10.1039/c1ob05729d

Publication date:

2011

Document version

Early version, also known as pre-print

Citation for published version (APA):

Hjelmgaard, T., Faure, S., Stærk, D., Taillefumier, C., \& Nielsen, J. (2011). Efficient and versatile COMUmediated solid-phase submonomer synthesis of arylopeptoids (oligomeric $\mathrm{N}$-substituted aminomethyl benzamides). Organic \& Biomolecular Chemistry, 9, 6832-6843. https://doi.org/10.1039/c1ob05729d 


\title{
Organic \& \\ Biomolecular \\ Chemistry
}

\section{Efficient and versatile COMU-mediated solid-phase submonomer synthesis of arylopeptoids (oligomeric $N$-substituted aminomethyl benzamides) $\dagger$}

\author{
Thomas Hjelmgaard, ${ }^{* a}$ Sophie Faure, ${ }^{b, c}$ Dan Staerk, ${ }^{a}$ Claude Taillefumier ${ }^{b, c}$ and John Nielsen $* a$ \\ Received 9th May 2011, Accepted 6th July 2011 \\ DOI: $10.1039 /$ c1ob05729d

\begin{abstract}
The development of a highly efficient methodology for solid-phase synthesis of para- and $m e t a$-arylopeptoids (oligomeric $N$-substituted aminomethyl benzamides) with free acids or free amides at the $C$-terminus is described. The arylopeptoids were synthesised by means of a convenient submonomer protocol in which the arylopeptoid residues were created in an iterative manner on the growing chain using an acylation-substitution cycle. The uronium salt COMU was found to be the most efficient reagent for ensuring fast and clean couplings of the benzoic acid building blocks.
\end{abstract}

\section{Introduction}

A group of foldamers which has received ever increasing interest during the last two decades is "one-way sequence" aromatic oligoamides comprised of aromatic amino acids. ${ }^{1}$ While the amide core structures of these synthetic oligomers are inherently only distantly related to biopolymers such as peptides, they may still be brought to mimic the side chain presentation and structure of such biopolymers and may therefore for example find use as proteomimetics. ${ }^{2}$ These aromatic oligoamides may be divided into two distinct groups: (i) aromatic oligoamides with free amide protons (Fig. 1a) and (ii) $N$-alkylated aromatic oligoamides (Fig. 1b).

In the first group, oligoamides that contain no aliphatic carbons in the backbone are by far the most widely studied (Fig. 1a). Examples include benzanilides by the groups of Hamilton, ${ }^{3}$ Gong, ${ }^{4}$ Kilbinger, ${ }^{5} \mathrm{Li}^{6}{ }^{6}$ Wilson, ${ }^{7}$ Clayden, ${ }^{8}$ and others: ${ }^{9}$ pyridylamides by the Hamilton group ${ }^{3 a-b, 10}$ and quinoline and naphthyridine oligoamides by the Huc group. ${ }^{11,12}$ The syntheses of these oligomers pass via acylation of comparatively less reactive aromatic amines and coupling using acid chlorides is the most commonly used synthetic pathway, primarily in solution, ${ }^{3,4,5 \mathrm{c}, 6-8,9 \mathrm{a}-\mathrm{c}, \mathrm{e}, 11,10}$ but also on solid-phase. ${ }^{\text {5a-b,9d }}$ Accordingly, the only reports of synthesis using free acid building blocks

${ }^{a}$ Department of Basic Sciences and Environment, University of Copenhagen, Thorvaldsensvej 40, 1871 Frederiksberg C, Denmark. E-mail: thhj@life.ku.dk, jn@life.ku.dk; Fax:+45 3533 2398;Tel: +453533 2427

${ }^{b}$ CNRS, UMR6504, Laboratoire SEESIB, 63177 Aubière cedex, France 'Clermont Université, Université Blaise Pascal, BP 10448, 63000 ClermontFerrand, France. E-mail: sophie.faure@univ-bpclermont.fr, claude. taillefumier@univ-bpclermont.fr

$\dagger$ Electronic supplementary information (ESI) available: Synthesis of halomethyl-intermediates $\boldsymbol{p}$-2 and $\boldsymbol{p}$-3; methods used for analytical and preparative HPLC; determination of the loading of the 2-chlorotrityl chloride polystyrene resin; details concerning optimisation of acylation and substitution steps using HPLC; HPLC profiles and NMR spectra of all synthesised arylopeptoids. See DOI: 10.1039/c1ob05729d a)<smiles>[R]c1cccc(CC)c1NCCC</smiles>

o/m/p-benzanilide $(\mathrm{X}=\mathrm{CH})$ p-pyridylamide $(X=N)$

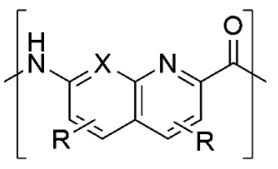

quinoline $(X=C H)$ naphthyridine $(X=N)$

b)

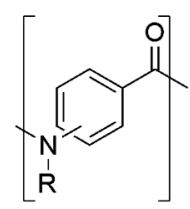

N-alkylated $m / p$-benzanilides<smiles>CC(=O)COc1ccccc1NC(C)(C)C</smiles>

aminophenoxy acetic acid<smiles>CCC(=O)Cc1ccccc1CNC</smiles>

aminomethylphenyl acetic acid

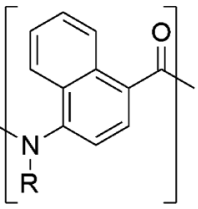

N-alkylated naphthanilide

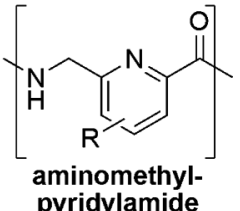

pyridylamide
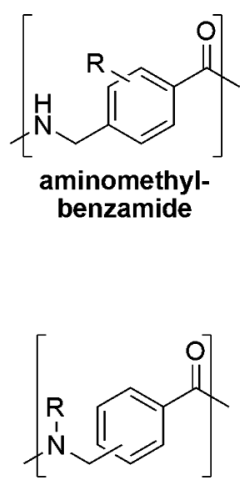

m/p-arylopeptoids

( $N$-alkylated m/p-aminomethyl-

benzamides)
Fig. 1 Aromatic oligoamides with free amide protons (a) and $N$-alkylated aromatic oligoamides (b).

and peptide-type coupling methods include the use of $\mathrm{BOP}^{9 \mathrm{~b}}$ or $\mathrm{PyBOP}^{12}$ in solution-phase. Although less well studied, several reports on aromatic oligoamides with free amide protons and aliphatic carbons in the backbone have been disclosed: oligoamides of aminomethyl-phenyl acetic acids by the Amblard group,$^{13}$ oligoamides of aminophenoxy acetic acids by the Akazome group, ${ }^{14}$ aminomethyl-pyridylamides by the Huc group, ${ }^{15}$ and aminomethyl-benzamides by the Hamilton group. ${ }^{16}$ Since the syntheses of these oligomers proceed via more reactive aliphatic intermediates, activation as acid chlorides is not necessary and they have exclusively been synthesised using peptide-type coupling 
reagents such as BOP, ${ }^{13} \mathrm{EDC},{ }^{14} \mathrm{HBTU},{ }^{15}$ in solution-phase and $\mathrm{PyBOP}^{16}$ on solid-phase. A common trait in this first group of aromatic oligoamides is that the formation of secondary structures may be promoted by the presence of intramolecular hydrogen bonding involving the free amide protons analogous to what is observed in peptides. Accordingly, the presence of spherand or crown ether-like structures, ${ }^{6}$ crescent or helical structures, ${ }^{4,11-14}$ and rodlike structures, ${ }^{5 a, c, 7 a}$ as well as the use as $\alpha$-helix mimetics, ${ }^{3 a-b, 7 a, 9 a-b, 10}$ has been reported.

Compared to aromatic oligoamides with free amide protons, $N$ alkylated aromatic oligoamides remain far less studied (Fig. 1b). Most of the efforts concerning $N$-alkylated oligoamides have again been concentrated around the synthesis and study of oligomers with no aliphatic carbons in the backbone, including $N$-alkylated benzanilides by the groups of Yokozawa, ${ }^{17}$ Kilbinger, ${ }^{18}$ Wilson, ${ }^{19}$ and Clayden; ${ }^{8 a}$ and $N$-alkylated naphthanilides by the Clayden group. ${ }^{\text {aa }}$ These oligomers were exclusively synthesised using activation as acid chlorides either in solution-phase ${ }^{8 \mathrm{a}, 17,19 b-\mathrm{c}}$ or on solid-phase. ${ }^{18 a-b, 19 a}$ Intriguingly, although they are deprived of free amide protons, the presence of crescent or helical structures ${ }^{17}$ as well as the use as $\alpha$-helix mimetics ${ }^{19 a}$ has still been reported. Furthermore, in connection with their pioneering work on the development of peptoids (oligomeric $N$-substituted glycines), ${ }^{20}$ Zuckermann and co-worker $\mathrm{s}^{21}$ briefly mentioned the synthesis of a few pentamers of para-arylopeptoids ${ }^{22}$ (oligomeric $N$-substituted aminomethyl benzamides) in a series of patents from the mid to late 90's. The oligomers were synthesised on a Rink amide polystyrene resin using a submonomer method unique to peptoids and the benzoic acid building blocks were activated as their corresponding anhydrides using 0.5 equiv DIC. In 2007, Lokey and Combs then reported the synthesis of a few tetramers and pentamers of paraor meta-arylopeptoids using a Wang resin and activation of the benzoic acid building blocks with 1.0 equiv DIC. ${ }^{23}$ This method was, however, not adaptable to synthesis on a Rink amide resin and provided mediocre yields.

We believe that these arylopeptoids may represent a new group of oligomers with folding propensities as a result of their relatively rigid aromatic amide core structure even though their backbones are deprived of free amide protons. Importantly, they may be developed to retain the favorable characteristics of peptoids such as large potential for diversity and straightforward synthesis using submonomer methods. Thus, based on convenient methods we have previously developed for solutionphase synthesis of peptoid residues, ${ }^{24}$ we recently published the first solution-phase synthesis of para- and meta-arylopeptoids. ${ }^{25}$ Shorter oligomers were synthesised using highly convenient and efficient submonomer protocols where each arylopeptoid residue is created in an iterative manner on the growing chain using an acylation-substitution cycle. Peptide coupling methods were studied to access longer oligomers and we furthermore undertook the first conformational studies of arylopeptoids. Thus, the cis/trans isomerism of arylopeptoid backbones was studied by means of NMR and we found that increasing the bulkiness of the side chains would greatly favor the cis amide bond conformation. Although this solution-phase methodology is highly useful for gram scale synthesis of lead compounds, the development of efficient and generally applicable solid-phase methodologies for synthesis of large and diversified libraries of arylopeptoids is highly desirable. Thus, herein we describe the development of a versatile COMU-based solid-phase methodology that meets these demands.

\section{Results and discussion}

\section{Solution-phase studies}

In order to establish the initial conditions for optimisation of solidphase submonomer synthesis of arylopeptoids, we first screened a series of coupling and substitution conditions on a small scale in solution (see ESI $\uparrow$ for details). As a model system for conducting these studies we used conversion of para-monomer $\boldsymbol{p}-\mathbf{1},{ }^{25}$ carrying the moderately bulky isopropyl side chain, into dimer $p-4^{25}$ via bromomethyl intermediate $\mathbf{p - 2}$ or chloromethyl intermediate $\boldsymbol{p} \mathbf{- 3}$ (Scheme 1).

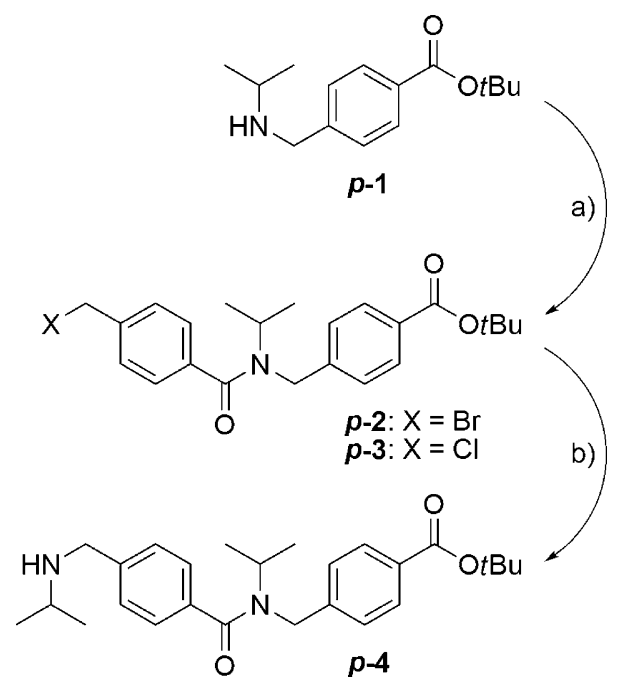

Scheme 1 Model system for solution-phase studies. Key: (a) $\mathrm{XCH}_{2} \mathrm{ArCOOH}$, coupling reagent, DIPEA, solvent, rt, further conditions in Table 1. (b) $i \mathrm{PrNH}_{2}$, solvent, further conditions in Table 2.

In our preceding paper, we screened a selection of coupling reagents for peptide-type coupling of arylopeptoid trimers. ${ }^{25} \mathrm{We}$ found the new uronium salt $\mathrm{COMU}^{26}$ (derived from Oxyma) to be by far the most efficient coupling reagent and we therefore started the present study with the use of COMU. Thus, $1 \mathrm{M}$ solutions of 4-(bromomethyl)benzoic acid or 4-(chloromethyl)benzoic acid (3 equiv) in DMF were preactivated with COMU (3.5 equiv) and DIPEA (7 equiv) at room temperature, and were then reacted with monomer $\boldsymbol{p}$-1. The reactions were monitored by analytical HPLC (see ESI $\uparrow$ for details) and while the conversion of $\boldsymbol{p}-\mathbf{1}$ into bromomethyl intermediate $\boldsymbol{p} \mathbf{- 2}$ gave rise to a complex reaction mixture (Table 1, entry 1 ) the conversion of $\boldsymbol{p}-\mathbf{1}$ into chloromethyl intermediate $\boldsymbol{p}-\mathbf{3}$ proceeded cleanly in $2.5 \mathrm{~min}$ (Table 1 , entry 2 ). Indeed, we found that while 4-(chloromethyl)benzoic acid remains reasonably pure in DMF in the presence of DIPEA $(99.6 \%$ purity after $5 \mathrm{~min} ; 98.5 \%$ purity after $15 \mathrm{~min}$ ), 4-(bromomethyl)benzoic acid polymerises quickly under the same conditions $(<50 \%$ purity after $5 \mathrm{~min}$ ). These polymerisation reactions presumably occur too fast for COMU activation to compete properly and a complex product mixture is obtained. The use of 4-(bromomethyl)benzoic acid as a building block for solid-phase submonomer synthesis of arylopeptoids under basic conditions was therefore abandoned. 
Table 1 Optimisation of coupling step (a)

\begin{tabular}{|c|c|c|c|c|c|c|c|}
\hline Entry & $\begin{array}{l}\mathrm{X}, \mathrm{XCH}_{2} \mathrm{C}_{6} \mathrm{H}_{4} \mathrm{COOH} \\
\text { (equiv) }\end{array}$ & $\begin{array}{l}\text { Coupling reagent } \\
\text { (equiv) }\end{array}$ & $\begin{array}{l}\text { DIPEA } \\
\text { (equiv) }\end{array}$ & Solvent & $\begin{array}{l}\text { Pre-activation } \\
\text { (min) }\end{array}$ & $\begin{array}{l}\text { Reaction time }{ }^{a} \\
(\min )\end{array}$ & Comments \\
\hline 1 & $\operatorname{Br}(3.0)$ & COMU (3.5) & 7.0 & DMF & 5 & $<2.5$ & Complex mixture \\
\hline 2 & $\mathrm{Cl}(3.0)$ & COMU (3.5) & 7.0 & DMF & 5 & 2.5 & Clean reaction to $\mathrm{p}-3$ \\
\hline 3 & $\mathrm{Cl}(3.0)$ & COMU (3.5) & 7.0 & NMP & 5 & 5 & Clean reaction to $\mathrm{p}-\mathbf{3}$ \\
\hline 4 & $\mathrm{Cl}(3.0)$ & HOTU (3.5) & 7.0 & NMP & 5 & 10 & Clean reaction to $\mathbf{p}-3$ \\
\hline 5 & $\mathrm{Cl}(3.0)$ & HATU (3.5) & 7.0 & NMP & 5 & 20 & Clean reaction to $\mathbf{p}-\mathbf{3}$ \\
\hline 6 & $\mathrm{Cl}(3.0)$ & PyBroP (3.5) & 7.0 & NMP & 5 & 30 & Clean reaction to $\mathrm{p}-\mathbf{3}$ \\
\hline 7 & $\mathrm{Cl}(3.0)$ & $\mathrm{BOP}(3.5)$ & 7.0 & NMP & 5 & $>30$ & $93 \%$ conv. after $30 \mathrm{~min}$ \\
\hline 8 & $\mathrm{Cl}(3.0)$ & HBTU (3.5) & 7.0 & NMP & 5 & $>30$ & $90 \%$ conv after $30 \mathrm{~min}$ \\
\hline 9 & $\mathrm{Cl}(3.0)$ & PyBOP (3.5) & 7.0 & NMP & 5 & $>30$ & $85 \%$ conv. after $30 \mathrm{~min}$ \\
\hline 10 & $\mathrm{Cl}(6.0)$ & $\mathrm{DIC}(3.0)$ & 7.0 & NMP & 5 & $>30$ & $93 \%$ conv. after $30 \mathrm{~min}$ \\
\hline 11 & $\mathrm{Cl}(3.0)$ & $\operatorname{DIC}(3.0)$ & 0 & NMP & 5 & $>30$ & $83 \%$ conv. after $30 \mathrm{~min}$ \\
\hline
\end{tabular}

${ }^{a}$ Reactions monitored by analytical HPLC.

Next, we found that although the conversion of $\boldsymbol{p}-\mathbf{1}$ into $\boldsymbol{p}-\mathbf{3}$ would proceed slightly slower when using the less toxic NMP as solvent (5 min, entry 3), the reaction would proceed just as cleanly as in DMF. A representative selection of other coupling agents were then screened (entries 4-11). Although most of these couplings proceeded with the same purity as when COMU was used, none of the alternative coupling reagents could compete with COMU with respect to reaction times. Thus, compared to COMU, HOTU would double the reaction time $(10 \mathrm{~min}$, entry 4), while couplings using HATU and PyBroP would need $20 \mathrm{~min}$ and $30 \mathrm{~min}$ to reach completion, respectively (entries 5 and 6). Furthermore, couplings using BOP, HBTU and PyBOP did not reach complete conversion within 30 min (entries 7-9). Interestingly, both activation of 4-(chloromethyl)benzoic acid as the corresponding anhydride using 0.5 equiv DIC, as reported in the patents of Zuckermann and co-workers, ${ }^{21}$ and coupling using 1.0 equiv DIC as reported by Lokey, ${ }^{23}$ were found to be much less efficient than COMU couplings $(93 \%$ and $83 \%$ conversion after $30 \mathrm{~min}$, respectively, entries 10 and 11). Having established the combination of 4-(chloromethyl)benzoic acid and COMU as the optimal set of conditions for peptide type coupling synthesis of $\boldsymbol{p}-\mathbf{3}$, we then proceeded to investigate the ensuing substitution reaction with isopropylamine, yielding dimer $\boldsymbol{p}-\mathbf{4}$ (Table 2).
Although we had by now excluded the use of bromomethyl intermediate $\boldsymbol{p}-\mathbf{2}$, an initial solvent scan was performed using this more reactive intermediate. Thus, $\boldsymbol{p}-\mathbf{2}$ was reacted with 10 equiv isopropylamine as $1 \mathrm{M}$ solutions in different solvents at room temperature (Table 2, entries 1-6) and the evolution of the reactions was followed using analytical HPLC (see ESI $\uparrow$ for details). We found the substitution reaction to occur the fastest in DMSO ( $<2$ min, entry 6) followed by DMF and NMP (3 min, entries 4-5). When transferring these conditions to the corresponding chloromethyl intermediate $\boldsymbol{p}-\mathbf{3}$, the reaction times were as expected drastically increased (entries 7-9) with DMSO still offering the fastest reaction time ( $3 \mathrm{~h}$, entry 9). By increasing the concentration of isopropylamine and the temperature, the reaction time could be reduced (entries 10-12) and the reaction would be complete within a reasonable $30 \mathrm{~min}$ when using 20 equiv isopropylamine at $2 \mathrm{M}$ concentration in DMSO at $50{ }^{\circ} \mathrm{C}$ (entry 12). The reaction could also be performed in DMSO-water 9:1 although the reaction time increased slightly to $45 \mathrm{~min}$. This result indicated that concentrated aqueous solutions could be used as a source of small volatile amines if needed. We also tested the use of microwave irradiation $\left(95{ }^{\circ} \mathrm{C}\right)$ and found that the reaction times could be drastically reduced to $5 \mathrm{~min}$ or less (entries 14-16). Overall, these solutionphase investigations showed that the optimisation of solid-phase

Table 2 Optimisation of substitution step (b)

\begin{tabular}{|c|c|c|c|c|c|}
\hline Entry & $\mathrm{X}$ & $i \operatorname{PrNH}_{2}($ equiv/[c]) & Solvent & Conditions & Reaction time ${ }^{a}$ \\
\hline 1 & $\mathrm{Br}$ & $10.0 / 1.0$ & $\mathrm{MeOH}$ & $\mathrm{rt}$ & $4 \mathrm{~h}$ \\
\hline 2 & $\mathrm{Br}$ & $10.0 / 1.0$ & THF & $\mathrm{rt}$ & $1.5 \mathrm{~h}$ \\
\hline 3 & $\mathrm{Br}$ & $10.0 / 1.0$ & $\mathrm{CH}_{2} \mathrm{Cl}_{2}$ & $\mathrm{rt}$ & $1.5 \mathrm{~h}$ \\
\hline 4 & $\mathrm{Br}$ & $10.0 / 1.0$ & NMP & $\mathrm{rt}$ & $3 \min$ \\
\hline 5 & $\mathrm{Br}$ & $10.0 / 1.0$ & DMF & $\mathrm{rt}$ & $3 \mathrm{~min}$ \\
\hline 6 & $\mathrm{Br}$ & $10.0 / 1.0$ & DMSO & $\mathrm{rt}$ & $<2 \min$ \\
\hline 7 & $\mathrm{Cl}$ & $10.0 / 1.0$ & NMP & $\mathrm{rt}$ & $16 \mathrm{~h}$ \\
\hline 8 & $\mathrm{Cl}$ & $10.0 / 1.0$ & DMF & $\mathrm{rt}$ & $12 \mathrm{~h}$ \\
\hline 9 & $\mathrm{Cl}$ & $10.0 / 1.0$ & DMSO & $\mathrm{rt}$ & $3 \mathrm{~h}$ \\
\hline 10 & $\mathrm{Cl}$ & $20.0 / 2.0$ & DMSO & $\mathrm{rt}$ & $2 \mathrm{~h}$ \\
\hline 11 & $\mathrm{Cl}$ & $20.0 / 2.0$ & DMSO & $40{ }^{\circ} \mathrm{C}$ & $45 \mathrm{~min}$ \\
\hline 12 & $\mathrm{Cl}$ & $20.0 / 2.0$ & DMSO & $50{ }^{\circ} \mathrm{C}$ & $30 \mathrm{~min}$ \\
\hline 13 & $\mathrm{Cl}$ & $20.0 / 2.0$ & DMSO-water $9: 1$ & $50{ }^{\circ} \mathrm{C}$ & $45 \mathrm{~min}$ \\
\hline 14 & $\mathrm{Cl}$ & $10.0 / 1.0$ & DMSO & $\mathrm{MW}, 95^{\circ} \mathrm{C}$ & $5 \mathrm{~min}$ \\
\hline 15 & $\mathrm{Cl}$ & $20.0 / 2.0$ & DMSO & $\mathrm{MW}, 95^{\circ} \mathrm{C}$ & $<2.5 \mathrm{~min}$ \\
\hline 16 & $\mathrm{Cl}$ & $20.0 / 2.0$ & DMSO-water $9: 1$ & $\mathrm{MW}, 95^{\circ} \mathrm{C}$ & $<2.5 \mathrm{~min}$ \\
\hline
\end{tabular}

${ }^{a}$ Reactions monitored by analytical HPLC. 


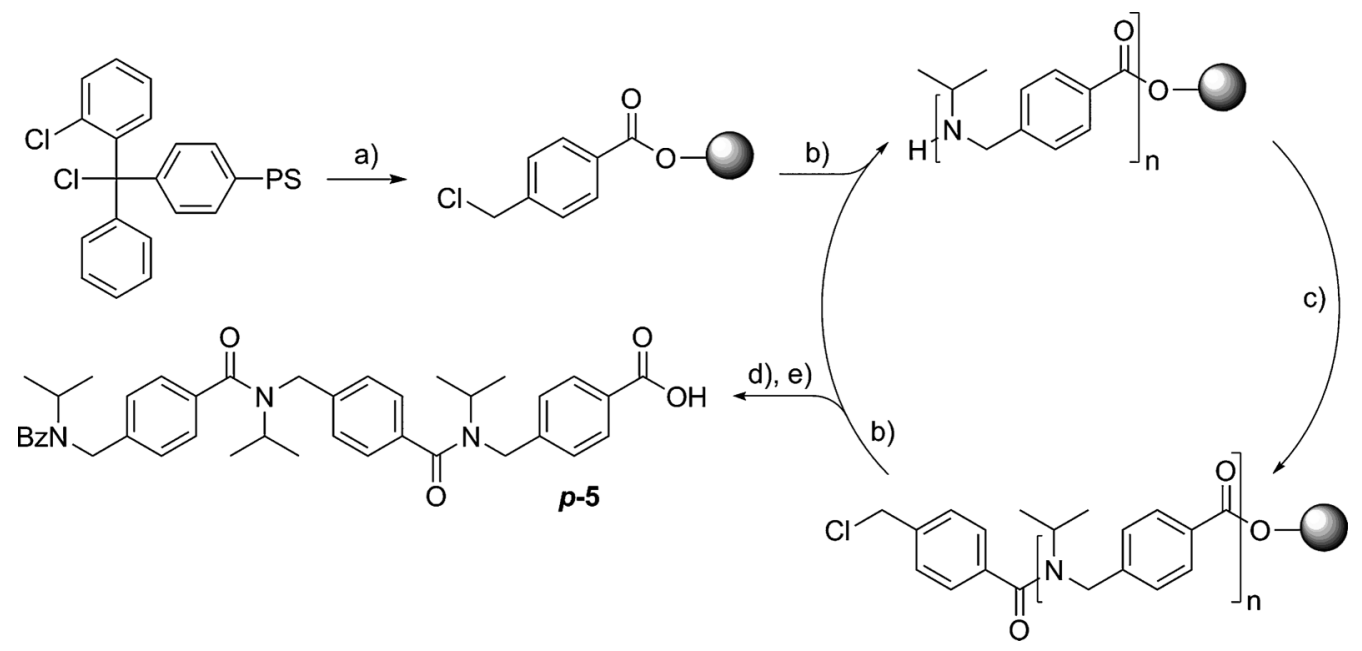

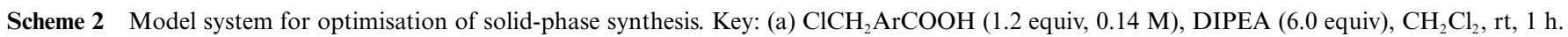
(b) $i \mathrm{PrNH}_{2}\left(20\right.$ equiv, $2.0 \mathrm{M}$ ), DMSO, further conditions in Table 3. (c) $\mathrm{ClCH}_{2} \mathrm{ArCOOH}, \mathrm{COMU}$, DIPEA, further conditions in Table 3. (d) BzCl (4.0 equiv, $1.0 \mathrm{M}$ ), DIPEA (8.0 equiv), $\mathrm{CH}_{2} \mathrm{Cl}_{2}$, rt, 15 min. (e) $\mathrm{HFIP}-\mathrm{CH}_{2} \mathrm{Cl}_{2} 1: 4, \mathrm{rt}, 1 \mathrm{~h}$.

submonomer synthesis of arylopeptoids should be based on the use of COMU-mediated coupling of chloromethylbenzoic acid building blocks and substitution reactions with primary amines in DMSO either at $50{ }^{\circ} \mathrm{C}$ or by the use of microwave activation.

\section{Solid-phase studies}

Optimisation of solid-phase submonomer synthesis of arylopeptoids was performed on a 2-chlorotrityl chloride polystyrene resin with a listed loading of $1.50 \mathrm{mmol} \mathrm{g}^{-1}$. As a direct continuation of the solution-phase studies we chose to use para-trimer $\boldsymbol{p}-\mathbf{5}$ with isopropyl side chains as a model target (Scheme 2). We found that a constant loading of $1.23 \pm 0.03 \mathrm{mmol} \mathrm{g}^{-1}$ was obtained when the 2-chlorotrityl chloride polystyrene resin was reacted with 4-(chloromethyl)benzoic acid (1.2 equiv with respect to the listed loading) in the presence of DIPEA (6.0 equiv) in $\mathrm{CH}_{2} \mathrm{Cl}_{2}$ at $\mathrm{rt}$ for $1 \mathrm{~h}$ (see ESI $\dagger$ for details). A slightly lower loading of $1.10 \mathrm{mmol} \mathrm{g}^{-1}$ was obtained when shortening the reaction time to $30 \mathrm{~min}$, while longer reaction times were avoided in order to minimise the risk of polymerisation of 4-(chloromethyl)benzoic acid. The synthesis of trimer $\boldsymbol{p} \mathbf{- 5}$ was then carried out by following the iterative coupling-substitution cycle illustrated in Scheme 2 followed by capping with benzoyl chloride and cleavage with HFIP. Based on the solution-phase studies, the reaction times of the substitution steps and coupling steps were set to $1 \mathrm{~h}$ and $20 \mathrm{~min}$, respectively, and we were satisfied to find that trimer p-5 could be isolated in 71-74\% crude yield and an excellent $96 \%$ crude purity when otherwise adapting the conditions found in the previous solution-phase studies (Table 3 , entry 1 ). We furthermore obtained identical crude yields and purities when conducting the coupling steps at higher dilution $(0.5 \mathrm{M})$ which would prove to be useful when synthesising longer oligomers (vide infra). Increasing the amount of COMU-activated 4-(chloromethyl)benzoic acid added in the coupling steps to 5 equiv did not improve the crude yield or purity of the synthesis (entry 2). The substitution steps could also be performed using microwave irradiation at $95{ }^{\circ} \mathrm{C}$ which would furnish trimer $\boldsymbol{p}-\mathbf{5}$ in comparable crude yields and purities (entry 3). However, although the reaction time of the substitution steps could be reduced to as little as $2.5 \mathrm{~min}$, we found heating to $50{ }^{\circ} \mathrm{C}$ using conventional heating blocks to be more convenient since the entire arylopeptoid synthesis could be completed without changing the reaction syringe. Otherwise, specialised equipment would be required. Attempts to change the initially selected reaction times did not improve the synthesis either. Thus, reducing the reaction time of the substitution steps to $15 \mathrm{~min}$ (entry 4 ) or increasing the reaction time of the coupling steps to $1 \mathrm{~h}$ (entry 5) would in both cases decrease the crude purity slightly to $93 \%$. Furthermore, reducing the reaction time of the

Table 3 Optimisation of substitution step (b) and coupling step (c)

\begin{tabular}{|c|c|c|c|c|c|c|c|}
\hline Entry & $\begin{array}{l}\text { Substitution step (b) } \\
\text { (temp/time) }\end{array}$ & \multicolumn{4}{|l|}{ Coupling step (c) } & $\begin{array}{l}\text { Crude } \\
\text { yield }(\%)\end{array}$ & $\begin{array}{l}\text { Crude } \\
\text { purity }(\%)^{a}\end{array}$ \\
\hline 2 & $50^{\circ} \mathrm{C} / 1 \mathrm{~h}$ & $5.0 / 1.0$ & 6 & 12 & 20 & 76 & 96 \\
\hline 3 & $\mathrm{MW} 95^{\circ} \mathrm{C} / 2.5-10 \mathrm{~min}$ & $5.0 / 1.0$ & 6 & 12 & 20 & $73-75$ & 95 \\
\hline 4 & $50^{\circ} \mathrm{C} / 15 \mathrm{~min}$ & $3.0 / 1.0$ & 3.5 & 7 & 20 & 74 & 93 \\
\hline
\end{tabular}


<smiles>[R]C(CNc1ccc(C(=O)OCC(C)C)cc1)CC(C)C</smiles>

Scheme 3 Solid-phase submonomer synthesis of model arylopeptoid hexamers with free acids at the $C$-terminus. $\mathrm{Key}_{\text {: }}(\mathrm{a}) \mathrm{ClCH}_{2} \mathrm{ArCOOH}(1.2 \mathrm{equiv}$, 0.14 M), DIPEA (6.0 equiv), $\mathrm{CH}_{2} \mathrm{Cl}_{2}$, rt, 1 h. (b) R-NH $\mathrm{NH}_{2}\left(20\right.$ equiv, $2.0 \mathrm{M}$ ), DMSO, $50{ }^{\circ} \mathrm{C}, 1 \mathrm{~h}$. (c) $\mathrm{ClCH}_{2} \mathrm{ArCOOH}$ (3.0 equiv, $\left.1.0 \mathrm{M}\right)$, $\mathrm{COMU}$ (3.5 equiv), DIPEA (7.0 equiv), rt, 20 min. (d) BzCl (4.0 equiv, $1.0 \mathrm{M}$ ), DIPEA (8.0 equiv), $\mathrm{CH}_{2} \mathrm{Cl}_{2}$, rt, 15 min. (e) $\mathrm{HFIP}-\mathrm{CH}_{2} \mathrm{Cl}_{2} 1: 4, \mathrm{rt}, 1 \mathrm{~h}$. See Table 4 for yields and purities.

coupling step to 5 min would decrease the crude yield to $69 \%$ and at the same time decrease the crude purity to $82 \%$ (entry 6). Overall, the conditions listed in entry 1 were chosen as the optimal conditions.

\section{Solid-phase synthesis of arylopeptoids}

With an optimised method for solid-phase submonomer synthesis of arylopeptoids in hand, we then first synthesised a range of representative model para-hexamers $\mathbf{p}-\mathbf{6}$ and meta-hexamers $\boldsymbol{m}$-6 with free acids at the $C$-terminus (Scheme 3 and Table $4)$. The syntheses were performed on the 2-chlorotrityl chloride polystyrene resin used in the above studies using the optimised conditions. We were satisfied to find that hexamers $\boldsymbol{p} / \boldsymbol{m}-\mathbf{6 a}$ with isopropyl side chains, $\boldsymbol{p} / \boldsymbol{m}$-6c with 4-phenylbutyl side chains and $\boldsymbol{p} / \boldsymbol{m}$-6d with 2-morpholinoethyl side chains were all isolated in good crude purities (78-85\%, entries $1-2$ and 5-8). Whereas hexamer $\boldsymbol{p}$-6a unfortunately proved too insoluble to be purified, the remaining hexamers could easily be obtained in 39-58\% yield and $>99 \%$ purity after preparative HPLC. For comparison, Lokey and Combs reported the synthesis of similar $N$-acetyl capped para-and meta-arylopeptoid tetramers with 2-morpholinoethyl side chains in $20 \%$ and $37 \%$ yield, respectively, and the synthesis of similar $N$-acetyl capped para- and meta-arylopeptoid pentamers with 4-phenylbutyl side chains in $12 \%$ yield. ${ }^{23}$ Our method thus provides longer oligomers in greatly increased yields and is furthermore more efficient when installing more bulky side chains such as the isopropyl side chain. We used a concentrated aqueous solution as the source of ethylamine for the substitution steps in the synthesis of hexamers $\boldsymbol{p} / \boldsymbol{m}$-6b which carry ethyl side chains (entries 3 and 4). Although we had shown in the solution-phase studies that the substitution step would proceed more slowly in the presence of water, only a slight decrease in crude purity to $71 \%$ was observed. Hexamers $\boldsymbol{p}$-6b and $\boldsymbol{m}$-6b were isolated in comparable crude yields which were slightly lower than the above-mentioned hexamers. Hexamer p-6b unfortunately also proved too insoluble to allow for purification, but $\boldsymbol{m}$-6b was accordingly isolated in a slightly lower yield than the above-mentioned hexamers after purification $(33 \%$, $>99 \%$ purity, entry 4 ). This slight decrease in yield is presumably a result of slow ester hydrolysis of the arylopeptoid chains from the 2-chlorotrityl linker during the substitution reactions. Hexamer p-6e with pyridinylmethyl side chains was also synthesised efficiently although the crude purity was reduced to $52 \%$ and the yield of the purified product was only $21 \%$ (>99\% purity, entry 9 ). Synthesis of hexamers carrying highly bulky tert-butyl side chains was likewise attempted but failed to yield anything but complex product mixtures.

Table 4 Results for solid-phase submonomer synthesis of model arylopeptoid hexamers with free acids at the $C$-terminus

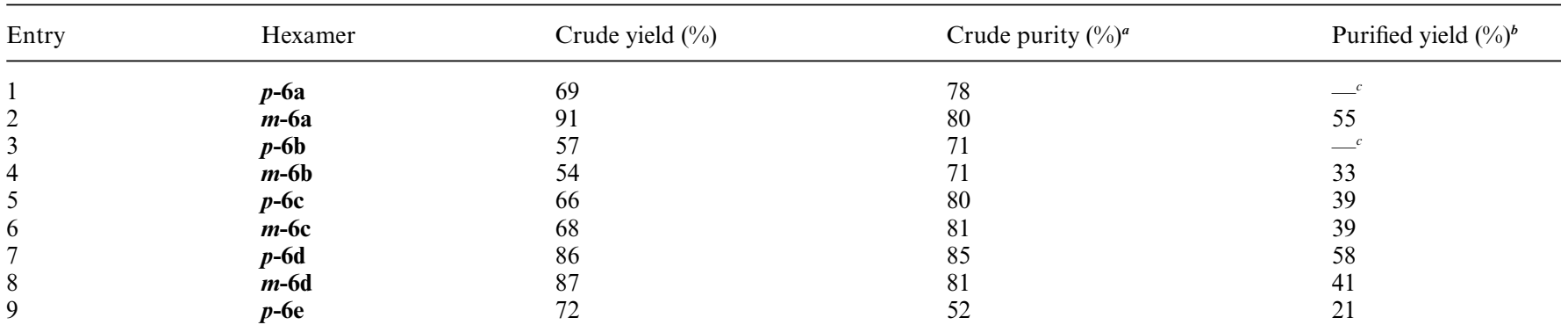

${ }^{a}$ Determined by analytical HPLC. ${ }^{b}$ Yield of product isolated in $>99 \%$ purity after preparative HPLC. ${ }^{c}$ Preparative HPLC hindered due to very low solubility. 


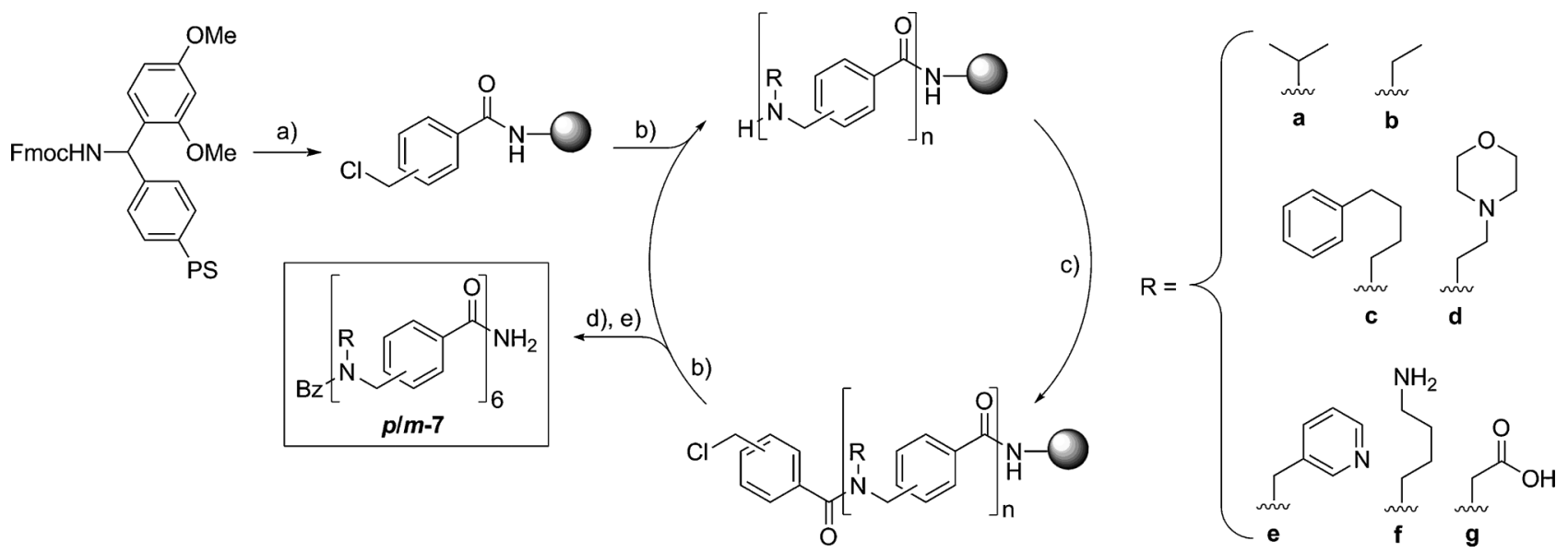

Scheme 4 Solid-phase submonomer synthesis of model arylopeptoid hexamers with free amide at the $C$-terminus. Key: (a) piperidine-NMP $1: 4$, rt, 2 and $15 \mathrm{~min}$; then $\mathrm{ClCH}_{2} \mathrm{ArCOOH}$ (3.0 equiv, 1.0 M), COMU (3.5 equiv), DIPEA (7.0 equiv), rt, 30 min. (b) R-NH $\mathrm{NH}_{2}\left(20\right.$ equiv, $2.0 \mathrm{M}$ ), DMSO, $50{ }^{\circ} \mathrm{C}$,

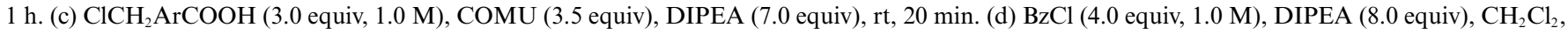
rt, 15 min. (e) TFA-water $95: 5$, rt, 2 h. See Table 5 for yields and purities.

An important point for us was to develop the first efficient and versatile solid-phase methodology for submonomer synthesis of arylopeptoids that could generate both oligomers with free acids at the $C$-terminus and oligomers with free amides at the $C$ terminus. Indeed, Lokey and Combs reported that their method was not adaptable to the use of Rink amide resins, ${ }^{23}$ while synthesis of arylopeptoids with free acids at the $C$-terminus was not demonstrated by Zuckermann and coworkers. ${ }^{21}$ We were therefore satisfied to find that our methodology was also adaptable to synthesis of oligomers with free amides at the $C$ terminus using a Rink amide polystyrene resin with a listed loading of $0.74 \mathrm{mmol} \mathrm{g}^{-1}$ (Scheme 4 and Table 5). Compared to synthesis using the 2-chlorotrityl chloride polystyrene resin, the only changes to the syntheses were (1) the initial attachment reactions were carried out for 30 min using 3 equiv of COMUactivated chloromethylbenzoic acids with respect to the listed resin loading and (2) the final cleavage was effected using TFA-water $95: 5$ instead of HFIP. Hexamers $\boldsymbol{p} / \boldsymbol{m}$-7a with isopropyl side chains, $\boldsymbol{p} / \boldsymbol{m}$-7c with 4-phenylbutyl side chains and $\boldsymbol{p} / \boldsymbol{m}$-7d with 2-morpholinoethyl side chains were all isolated in good crude purities (71-84\%, entries 1-2 and 4-7) and good purified yields after preparative HPLC $(46-59 \%,>99 \%$ purity). These results are comparable to the results obtained above in the synthesis of the analogous arylopeptoids with free acids at the $C$-terminus using the 2-chlorotrityl linker. The two linkers thus perform equally well with these side chains when applying the standard conditions we have developed. Furthermore, when using the Rink amide linker, we did not observe a relative decrease in the yield of $\boldsymbol{p}$-7b which carries ethyl side chains even though a concentrated aqueous solution was again used as the source of ethylamine (54\% yield, $>99 \%$ purity, entry 3 ). This supports the assumption that the relative reduction in yield of $\boldsymbol{p} / \boldsymbol{m}$ - $\mathbf{6} \mathbf{b}$ is caused by slow hydrolysis of the arylopeptoid chains from the 2-chlorotrityl linker during the substitution steps. Our results compare favourably with the method reported in the patents of Zuckermann and coworkers where similar, though $N$-uncapped, para-arylopeptoid pentamers were obtained in $60-76 \%$ crude yield and $80-90 \%$ crude purity. ${ }^{21}$ Installing pyridinylmethyl side chains again resulted in a reduced crude purity of $51 \%$ and we accordingly obtained $\boldsymbol{p}-7 \mathrm{e}$ in only $22 \%$ yield ( $>99 \%$ purity, entry 8 ). We furthermore synthesised hexamers $\boldsymbol{p}$-7f and $\boldsymbol{p}$-7g which carry 4 -aminobutyl side chains and carboxymethyl side chains, respectively (entries 9-10). These side chains were installed using tert-butyl (4-aminobutyl)carbamate and tert-butyl aminoacetate in the substitution steps, respectively, conveniently unmasking the side chain functionalities during the cleavage step.

Table 5 Results for solid-phase submonomer synthesis of model arylopeptoid hexamers with free amides at the $C$-terminus

\begin{tabular}{|c|c|c|c|c|}
\hline Entry & Hexamer & Crude yield (\%) & Crude purity $(\%)^{a}$ & Purified yield $(\%)^{b}$ \\
\hline 2 & $m-7 \mathbf{a}$ & 110 & 71 & 58 \\
\hline 4 & $p-7 c$ & 110 & 78 & 46 \\
\hline 5 & $m-7 c$ & 104 & 84 & 53 \\
\hline 6 & $p-7 \mathrm{~d}$ & 93 & 79 & 58 \\
\hline 7 & $m-7 \mathbf{d}$ & 115 & 81 & 59 \\
\hline 10 & $p-7 g$ & 109 & 52 & 31 \\
\hline
\end{tabular}

${ }^{a}$ Determined by analytical HPLC. ${ }^{b}$ Yield of product isolated in $>99 \%$ purity after preparative HPLC. 
In order to firmly underline the utility of the present method we then easily synthesised the longest arylopeptoid constructs demonstrated to date: the two hetero-dodecamers $\boldsymbol{p}-\mathbf{8}$ and $\boldsymbol{m - 8}$ shown in Scheme 5, which were obtained in $25 \%$ and $27 \%$ overall yield, respectively, after preparative HPLC ( $>99 \%$ purity). The syntheses were carried out as outlined in Scheme 4 with the only modifications being that coupling steps beyond the hexamer stage as well as the final capping step were carried out at higher dilution $(0.5 \mathrm{M})$ as a result of the expanding of the resin. The dodecamers were obtained in highly satisfactory $62 \%$ and $58 \%$ crude purities, respectively.
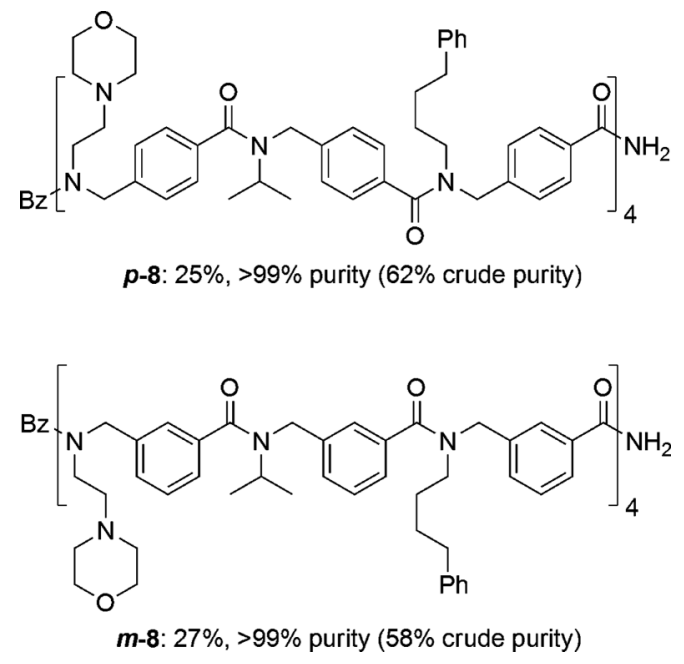

Scheme 5 Model hetero-dodecamers $p-\mathbf{8}$ and $\mathbf{m - 8}$

Importantly, we observed that the solubility of the synthesised arylopeptoid oligomers in different solvents would vary greatly as a function of the side chain decorations, the substitution patterns of the backbone and the nature of the $C$-terminus. Thus, arylopeptoids that carried hydrophobic side chains such as ethyl, isopropyl or 4-phenylbutyl were only soluble in organic solvents such as methanol or $\mathrm{CH}_{2} \mathrm{Cl}_{2}$ and the presence of only small amounts of water would be tolerated before cloudy mixtures formed. On the contrary, arylopeptoids that carried hydrophilic side chains such as pyridinylmethyl, 2-morpholinoethyl or 4aminobutyl were generally highly water soluble. Furthermore, we noted that meta-arylopeptoids were generally more readily soluble than para-arylopeptoids and that arylopeptoids with free amides at the $C$-terminus were likewise more readily soluble than arylopeptoids with free acids at the $C$-terminus. Overall, these observations lend promise that arylopeptoids may easily be adapted for a plethora of uses in chemical biology and medicine.

\section{Conclusions}

We have developed a highly efficient methodology for solidphase synthesis of para- and meta-arylopeptoids (oligomeric $N$-substituted aminomethyl benzamides). The oligomers were synthesised by means of a highly versatile submonomer protocol in which the arylopeptoid residues are created in an iterative manner on the growing chain using an acylation-substitution cycle. The difficult acylation steps of the secondary amines were conveniently carried out using free acid building blocks reminiscent of peptide synthesis, and we found the new uronium salt COMU to be the most efficient reagent for ensuring fast and clean couplings. The present methodology is the first that has been shown to be adaptable to synthesis of arylopeptoids with both free acids and free amides at the $C$-terminus. We found the solubility of arylopeptoids in different solvents to vary greatly as a function of the side chain decorations, the substitution patterns of the backbone and the nature of the $C$-terminus, lending promise that arylopeptoids may easily be adapted for a plethora of uses within for example chemical biology and medicine. The developed solidphase methodology will allow for synthesis of highly diversified libraries of arylopeptoids and we will continue to explore all aspects of arylopeptoids and will report our findings in due course.

\section{Experimental Section}

\section{General experimental methods}

$\mathrm{CH}_{2} \mathrm{Cl}_{2}$ used as solvent in attachment and capping reactions was dried over $4 \AA$ molecular sieves. All other chemicals and solvents obtained from commercial sources (Alfa Aesar, Fluka, Merck and Sigma-Aldrich) were used as received. 2-Chlorotrityl chloride copoly(styrene-1\% DVB) resin (100-200 mesh) with a listed loading of $1.50 \mathrm{mmol} \mathrm{g}^{-1}$ and Rink amide copoly(styrene- $1 \%$ DVB) resin (100-200 mesh) with a listed loading of $0.74 \mathrm{mmol} \mathrm{g}^{-1}$ were purchased from Merck. $2 \mathrm{M}$ solutions of primary amines in DMSO used in the substitution steps were made from the neat, free amines except in the case of ethylamine where a saturated aqueous solution was used as a source of the amine. Melting points were determined on a Mettler Toledo MP70 melting point system and are referenced to the melting points of benzophenone and benzoic acid. NMR spectra were recorded on a Bruker Avance $300 \mathrm{MHz}$ spectrometer. Chemical shifts are referenced to the residual solvent peak and $J$ values are given in Hz. The following multiplicity abbreviations are used: (s) singlet, (q) quartet, (m) multiplet, and (br) broad. Where applicable, assignments were based on COSY, HMBC, HSQC and $J$-mod-experiments. IR spectra were recorded on a Shimadzu FTIR-8400S spectrometer equipped with a Pike Technologies MIRacle ${ }^{\mathrm{TM}}$ ATR and wavenumbers $(v)$ are expressed in $\mathrm{cm}^{-1}$. HRMS of all arylopeptoids except for $\boldsymbol{p}-\mathbf{7 f}$ and $\boldsymbol{p}-\mathbf{7 g}$ were recorded on a Micromass LCT apparatus equipped with an AP-ESI probe calibrated with Leu-Enkephalin. HRMS of $\boldsymbol{p}$-7f and $\boldsymbol{p}-\mathbf{7} \mathbf{g}$ were recorded on a Micromass Q-Tof Micro (3000V) apparatus. Model system monomer $\boldsymbol{p}$-1 $\mathbf{1}$ and dimer $\boldsymbol{p} \mathbf{- 4}$ were synthesised as previously described ${ }^{25} \mathrm{See} \mathrm{ESI} \dagger$ for details concerning analytical and preparative HPLC as well as for the synthesis of halomethyl intermediates $\boldsymbol{p}-\mathbf{2}$ and $\boldsymbol{p}-\mathbf{3}$.

\section{General procedure for attachment to trityl resin and synthesis of first arylopeptoid residue}

2-Chlorotrityl chloride resin $\left(100 \mathrm{mg}, 1.50 \mathrm{mmol} \mathrm{g} \mathrm{g}^{-1}\right.$; thus $0.150 \mathrm{mmol})$ was washed with $\mathrm{CH}_{2} \mathrm{Cl}_{2}(2 \times 2 \mathrm{~mL})$. The resin was swelled in $\mathrm{CH}_{2} \mathrm{Cl}_{2}(2 \mathrm{~mL})$ for $5 \mathrm{~min}$ and drained. To a suspension of 3- or 4-(chloromethyl)benzoic acid $(30.7 \mathrm{mg}, 0.18 \mathrm{mmol})$ in $\mathrm{CH}_{2} \mathrm{Cl}_{2}(1.3 \mathrm{~mL})$ at $\mathrm{rt}$ was added DIPEA $(0.126 \mathrm{~mL}, 0.72 \mathrm{mmol})$. The resulting solution was added to the resin and the resulting mixture was agitated for $1 \mathrm{~h}$ at $\mathrm{rt}$ after which time a loading of $1.23 \pm 0.03 \mathrm{mmol}$ was obtained (see ESI $\dagger$ ). The resin was drained 
and washed with $\mathrm{CH}_{2} \mathrm{Cl}_{2}(3 \times 2 \mathrm{~mL})$ and DMSO $(3 \times 2 \mathrm{~mL})$. A solution of the secondary amine (20 equiv, $2 \mathrm{M})$ in DMSO $(1.3 \mathrm{~mL})$ was added to the resin and the mixture was agitated at $50{ }^{\circ} \mathrm{C}$ for $1 \mathrm{~h}$. The resin was drained and washed with DMSO $(3 \times 2 \mathrm{~mL})$ and NMP $(3 \times 2 \mathrm{~mL})$.

General procedure for attachment to rink amide resin and synthesis of first arylopeptoid residue

Rink amide resin (162 $\mathrm{mg}, 0.74 \mathrm{mmol} \mathrm{g}^{-1}$; thus $\left.0.120 \mathrm{mmol}\right)$ was washed with $\mathrm{CH}_{2} \mathrm{Cl}_{2}(2 \times 2 \mathrm{~mL})$ and NMP $(5 \times 2 \mathrm{~mL})$. PiperidineNMP $1: 4(1.0 \mathrm{~mL})$ was added and the resin was agitated for $2 \mathrm{~min}$ and drained. Further piperidine-NMP $1: 4(1.0 \mathrm{~mL})$ was added and the resin was agitated for $15 \mathrm{~min}$, drained and washed with NMP $(5 \times 2 \mathrm{~mL})$. To a solution of 3- or 4-(chloromethyl)benzoic acid $(64 \mathrm{mg}, 0.38 \mathrm{mmol})$ in NMP $(0.38 \mathrm{~mL})$ at $\mathrm{rt}$ was added COMU $(187 \mathrm{mg}, 0.44 \mathrm{mmol})$ and then DIPEA $(0.157 \mathrm{~mL}, 0.90 \mathrm{mmol})$. After agitating for $5 \mathrm{~min}$, the resulting deep red mixture was added to the resin and the resulting mixture was agitated for $30 \mathrm{~min}$ at rt. The resin was drained and washed with NMP $(5 \times 2 \mathrm{~mL})$ and DMSO $(3 \times 2 \mathrm{~mL})$. A solution of the secondary amine (20 equiv, $2 \mathrm{M})$ in DMSO $(1.3 \mathrm{~mL})$ was added to the resin and the mixture was agitated at $50{ }^{\circ} \mathrm{C}$ for $1 \mathrm{~h}$. The resin was drained and washed with DMSO $(3 \times 2 \mathrm{~mL})$ and NMP $(3 \times 2 \mathrm{~mL})$.

\section{General procedure for arylopeptoid residue synthesis}

To a solution of 3- or 4-(chloromethyl)benzoic acid $(64 \mathrm{mg}$, $0.38 \mathrm{mmol})$ in NMP $(0.38 \mathrm{~mL})$ at $\mathrm{rt}$ was added COMU (187 $\mathrm{mg}, 0.44 \mathrm{mmol})$ and then DIPEA $(0.157 \mathrm{~mL}, 0.90 \mathrm{mmol})$. After agitating for $5 \mathrm{~min}$, the resulting deep red mixture was added to the resin and the resulting mixture was agitated for $20 \mathrm{~min}$ at $\mathrm{rt}$. The resin was drained and washed with NMP $(5 \times 2 \mathrm{~mL})$ and DMSO $(3 \times 2 \mathrm{~mL})$. A solution of the secondary amine (20 equiv, $2 \mathrm{M})$ in DMSO $(1.3 \mathrm{~mL})$ was added to the resin and the mixture was agitated at $50{ }^{\circ} \mathrm{C}$ for $1 \mathrm{~h}$. The resin was drained and washed with DMSO $(3 \times 2 \mathrm{~mL})$ and NMP $(3 \times 2 \mathrm{~mL})$. This general procedure was repeated until the desired oligomer length was reached.

\section{General procedure for capping with benzoyl chloride}

The resin was washed with $\mathrm{CH}_{2} \mathrm{Cl}_{2}(3 \times 2 \mathrm{~mL})$. To a solution of benzoyl chloride $(0.060 \mathrm{~mL}, 0.52 \mathrm{mmol})$ in $\mathrm{CH}_{2} \mathrm{Cl}_{2}(0.52 \mathrm{~mL})$ at $\mathrm{rt}$ was added DIPEA $(0.181 \mathrm{~mL}, 1.04 \mathrm{mmol})$. The solution was added to the resin and the resulting mixture was agitated for 15 min at rt. The resin was drained and washed with $\mathrm{CH}_{2} \mathrm{Cl}_{2}-$ DIPEA 4:1 $(3 \times 1 \mathrm{~mL}$, only for arylopeptoids that contain side chains with basic functionalities), $\mathrm{CH}_{2} \mathrm{Cl}_{2}(3 \times 2 \mathrm{~mL})$, NMP $(3 \times$ $2 \mathrm{~mL})$ and $\mathrm{CH}_{2} \mathrm{Cl}_{2}(3 \times 2 \mathrm{~mL})$.

\section{General procedure for cleavage from trityl resin}

The resin was cleaved in HFIP/ $\mathrm{CH}_{2} \mathrm{Cl}_{2} 1: 4(1 \mathrm{~mL})$ with agitation for $1 \mathrm{~h}$. The resin was drained and washed with $\mathrm{CH}_{2} \mathrm{Cl}_{2}(5 \times$ $2 \mathrm{~mL}$ ). The solvents were evaporated under reduced pressure and the residue was evaporated with $\mathrm{CH}_{2} \mathrm{Cl}_{2}(3 \times 5 \mathrm{~mL})$ yielding the crude product which was purified by preparative HPLC (see ESI $\dagger$ for details).

\section{General procedure for cleavage from rink amide resin}

The resin was cleaved in TFA-water 95:5 $(2 \mathrm{~mL})$ with agitation for $2 \mathrm{~h}$. The resin was drained and washed with TFA $(2 \mathrm{~mL})$ and $\mathrm{CH}_{2} \mathrm{Cl}_{2}(5 \times 2 \mathrm{~mL})$. The solvents were evaporated under reduced pressure and the residue was evaporated with $\mathrm{CH}_{2} \mathrm{Cl}_{2}(3 \times$ $5 \mathrm{~mL}$ ) yielding the crude product which was purified by preparative HPLC (see ESI $\dagger$ for details).

Arylopeptoid trimer $\boldsymbol{p}$-5. Colorless foam $(52 \mathrm{mg}, 65 \%,>99 \%$ purity). mp $=87-90{ }^{\circ} \mathrm{C} .{ }^{1} \mathrm{H}$ NMR $\left(300 \mathrm{MHz}, \mathrm{CDCl}_{3}\right): \delta=$ 9.85-9.30 (br s, $1 \mathrm{H}, \mathrm{COOH}), 8.12-7.92(\mathrm{~m}, 2 \mathrm{H}), 7.62-6.98(\mathrm{~m}$, $15 \mathrm{H}$ ), $4.88-4.44$ (br s, $6 \mathrm{H}, 3 \times \mathrm{CONCH}_{2} \mathrm{Ar}$ ), $4.38-4.03$ (br m, $3 \mathrm{H}$, $\left.3 \times \mathrm{CONCH}\left(\mathrm{CH}_{3}\right)_{2}\right), 1.42-0.94(\mathrm{~m}, 18 \mathrm{H}) \mathrm{ppm} .{ }^{13} \mathrm{C} \mathrm{NMR}(75 \mathrm{MHz}$, $\left.\mathrm{CDCl}_{3}\right): \delta=172.7,172.6,170.5\left(4 \mathrm{C}_{\mathrm{q}}\right), 145.0,140.6,136.4,134.9$ $\left(7 \mathrm{C}_{\mathrm{q}}\right), 130.3,129.5,128.6,127.0,126.8,126.5,126.1(17 \mathrm{CH}), 51.0$ (br, $\left.3 \mathrm{CH}, 3 \times \mathrm{CONCH}\left(\mathrm{CH}_{3}\right)_{2}\right), 43.5$ (br, $3 \mathrm{CH}_{2}, 3 \times \mathrm{CONCH}_{2} \mathrm{Ar}$ ), $21.3\left(6 \mathrm{CH}_{3}\right)$ ppm. $v_{\max } / \mathrm{cm}^{-1}(\mathrm{ATR}) 2980(\mathrm{CH}), 1713(\mathrm{C}=\mathrm{O})$, $1627(\mathrm{C}=\mathrm{O}), 1464(\mathrm{CH}), 1439,1409,1339(\mathrm{OH}), 1174(\mathrm{CN})$, 1061. HRMS (TOF MS ES ${ }^{+}$) calcd for $\mathrm{C}_{40} \mathrm{H}_{46} \mathrm{~N}_{3} \mathrm{O}_{5}[\mathrm{M}+\mathrm{H}]^{+} \mathrm{m} / z$ 648.3432 , found 648.3425 .

Arylopeptoid hexamer $\boldsymbol{p}$-6a. Preparative HPLC of the crude product hindered due to very low solubility. Crude $\boldsymbol{p}$-6a: Pale rose foam $\left(97 \mathrm{mg}, 69 \%, 78 \%\right.$ purity). $\mathrm{mp}=223-228{ }^{\circ} \mathrm{C} .{ }^{1} \mathrm{H}$ NMR (300 MHz, $\left.\mathrm{CDCl}_{3}-\mathrm{MeOD} 1: 1\right): \delta=8.00-7.92(\mathrm{~m}, 2 \mathrm{H}), 7.54-7.10$ (m, 27H), 4.78-4.40 (br s, $12 \mathrm{H}, 6 \times \mathrm{CONCH}_{2} \mathrm{Ar}$ ), 4.24-4.04 (br $\left.\mathrm{m}, 6 \mathrm{H}, 6 \times \mathrm{CONCH}\left(\mathrm{CH}_{3}\right)_{2}\right), 1.32-1.00(36 \mathrm{H}, \mathrm{m}) \mathrm{ppm} . v_{\max } / \mathrm{cm}^{-1}$ (ATR) 2968, 2929, $1628(\mathrm{C}=\mathrm{O}), 1437,1404,1338(\mathrm{OH}), 1175$ (CN), 1054, 842. HRMS (TOF MS ES ${ }^{+}$) calcd for $\mathrm{C}_{73} \mathrm{H}_{85} \mathrm{~N}_{6} \mathrm{O}_{8}$ $[\mathrm{M}+2 \mathrm{H}]^{2+} \mathrm{m} / \mathrm{z}$ 587.3248, found 587.3250.

Arylopeptoid hexamer $\boldsymbol{m}$-6a. Colorless foam $(82 \mathrm{mg}, 55 \%$, $>99 \%$ purity). $\mathrm{mp}=80-83{ }^{\circ} \mathrm{C} .{ }^{1} \mathrm{H}$ NMR $\left(300 \mathrm{MHz}, \mathrm{CDCl}_{3}\right)$ : $\delta=10.06-9.68($ br s, $1 \mathrm{H}, \mathrm{COOH}), 8.10-7.83(\mathrm{~m}, 2 \mathrm{H}), 7.65-7.02$ (m, 27H), 4.84-4.40 (br s, $\left.12 \mathrm{H}, 6 \times \mathrm{CONCH}_{2} \mathrm{Ar}\right), 4.30-3.88$ (br m, $\left.6 \mathrm{H}, 6 \times \mathrm{CONCH}\left(\mathrm{CH}_{3}\right)_{2}\right), 1.42-0.84(\mathrm{~m}, 36 \mathrm{H}) \mathrm{ppm} .{ }^{13} \mathrm{C}$ NMR $\left(75 \mathrm{MHz}, \mathrm{CDCl}_{3}\right): \delta=172.6\left(7 \mathrm{C}_{\mathrm{q}}\right), 139.6,139.5,136.7,136.6$, $130.2\left(13 \mathrm{C}_{\mathrm{q}}\right), 131.8,129.5,128.8,128.6,128.5,128.1,128.0,126.1$, $124.6(29 \mathrm{CH}), 51.0\left(\mathrm{br}, 6 \mathrm{CH}, 6 \times \mathrm{CONCH}\left(\mathrm{CH}_{3}\right)_{2}\right), 43.4\left(\mathrm{br}, 6 \mathrm{CH}_{2}\right.$, $6 \times \mathrm{CONCH}_{2} \mathrm{Ar}$ ), $21.3\left(12 \mathrm{CH}_{3}\right) \mathrm{ppm} . v_{\max } / \mathrm{cm}^{-1}$ (ATR) 2980,1713 $(\mathrm{C}=\mathrm{O}), 1627(\mathrm{C}=\mathrm{O}), 1464(\mathrm{CH}), 1447,1410,1338(\mathrm{OH}), 1178$ (CN), 1062. HRMS (TOF MS ES ${ }^{+}$calcd for $\mathrm{C}_{73} \mathrm{H}_{85} \mathrm{~N}_{6} \mathrm{O}_{8}[\mathrm{M}+$ $2 \mathrm{H}]^{2+} \mathrm{m} / \mathrm{z} 587.3248$, found 587.3257 .

Arylopeptoid hexamer $\boldsymbol{p}$-6b. Preparative HPLC of the crude product hindered due to very low solubility. Crude $\boldsymbol{p}$ - $6 \mathbf{b}$ : Pale rose foam (77 mg, 57\%, 71\% purity). $\mathrm{mp}=123-128{ }^{\circ} \mathrm{C} .{ }^{1} \mathrm{H}$ NMR (300 MHz, $\left.\mathrm{CDCl}_{3} / \mathrm{MeOD} 1: 1\right): \delta=8.05-7.96(\mathrm{~m}, 2 \mathrm{H}), 7.52-$ $7.10(\mathrm{~m}, 27 \mathrm{H}), 4.85-4.48\left(\mathrm{br} \mathrm{m}, 12 \mathrm{H}, 12 \times \mathrm{CONCH}_{2} \mathrm{Ar}\right), 3.60-3.18$ (br $\left.\mathrm{m}, 12 \mathrm{H}, 12 \times \mathrm{CONCH}_{2} \mathrm{CH}_{3}\right), 1.30-1.01(\mathrm{~m}, 18 \mathrm{H}) \mathrm{ppm}$. $v_{\max } / \mathrm{cm}^{-1}$ (ATR) 2973, 2915, $1716(\mathrm{C}=\mathrm{O}), 1627(\mathrm{C}=\mathrm{O}), 1464$ (CH), 1429, $1312(\mathrm{OH}), 1262,1175(\mathrm{CN}), 1093,836$. HRMS (TOF MS ES ${ }^{+}$) calcd for $\mathrm{C}_{67} \mathrm{H}_{74} \mathrm{~N}_{6} \mathrm{O}_{8}[\mathrm{M}+2 \mathrm{H}]^{2+} \mathrm{m} / z$ 545.2779, found 545.2775.

Arylopeptoid hexamer $\boldsymbol{m}$-6b. Colorless oil (45 mg, 33\%, >99\% purity). ${ }^{1} \mathrm{H}$ NMR (300 $\left.\mathrm{MHz}, \mathrm{CDCl}_{3}\right): \delta=8.11-7.78(\mathrm{~m}, 2 \mathrm{H})$, 7.60-7.14 (m, 27H), 4.88-4.63 (br s, 7.20H, $6 \times \mathrm{CONCH}_{2} \mathrm{Ar}$, major rotamer), $4.63-4.36$ (br s, $4.80 \mathrm{H}, 6 \times \mathrm{CONCH}_{2} \mathrm{Ar}$, minor rotamer), $3.62-3.33\left(\mathrm{~m}, 4.80 \mathrm{H}, 6 \times \mathrm{CONCH}_{2} \mathrm{CH}_{3}\right.$, minor rotamer), 3.33$3.04\left(\mathrm{~m}, 7.20 \mathrm{H}, 6 \times \mathrm{CONCH}_{2} \mathrm{CH}_{3}\right.$, major rotamer), $1.32-0.94$ 
(m, 18H) ppm. ${ }^{13} \mathrm{C}$ NMR $\left(75 \mathrm{MHz}, \mathrm{CDCl}_{3}\right): \delta=172.2\left(7 \mathrm{C}_{\mathrm{q}}\right)$, $137.8,137.5,136.4,136.0\left(13 \mathrm{C}_{\mathrm{q}}\right), 129.7,129.1,128.9,128.6$, $126.4,125.6(29 \mathrm{CH}), 51.9\left(\mathrm{br}, 2.40 \mathrm{CH}_{2}, 6 \times \mathrm{CONCH}_{2} \mathrm{Ar}\right.$, minor rotamer), 47.1 (br, $3.60 \mathrm{CH}_{2}, 6 \times \mathrm{CONCH}_{2} \mathrm{Ar}$, major rotamer), 43.3 (br, $3.60 \mathrm{CH}_{2}, 6 \times \mathrm{CONCH}_{2} \mathrm{CH}_{3}$, major rotamer), 40.1 (br, $2.40 \mathrm{CH}_{2}, 6 \times \mathrm{CONCH}_{2} \mathrm{CH}_{3}$, minor rotamer), 13.7, $12.2\left(6 \mathrm{CH}_{3}\right)$ ppm. $v_{\max } / \mathrm{cm}^{-1}$ (ATR) 2992, 2933, $1714(\mathrm{C}=\mathrm{O}), 1627(\mathrm{C}=\mathrm{O})$, $1456(\mathrm{CH}), 1418,1290(\mathrm{OH}), 1192,1172(\mathrm{CN}), 1076,980,795$. HRMS (TOF MS ES ${ }^{+}$) calcd for $\mathrm{C}_{67} \mathrm{H}_{74} \mathrm{~N}_{6} \mathrm{O}_{8}[\mathrm{M}+2 \mathrm{H}]^{2+} \mathrm{m} / z$ 545.2779, found 545.2776.

Arylopeptoid hexamer p-6c. Colorless foam (82 mg, 39\%, $>99 \%$ purity). $\mathrm{mp}=51-54{ }^{\circ} \mathrm{C} .{ }^{1} \mathrm{H}$ NMR $\left(300 \mathrm{MHz}, \mathrm{CDCl}_{3}\right)$ : $\delta=8.58-8.18($ br s, $1 \mathrm{H}, \mathrm{COOH}), 8.11-8.00(\mathrm{~m}, 2 \mathrm{H}), 7.48-$ $6.95(\mathrm{~m}, 57 \mathrm{H}), 4.86-4.62$ (br s, $6.60 \mathrm{H}, 6 \times \mathrm{CONCH}_{2} \mathrm{Ar}$, major rotamer), $4.62-4.36$ (br s, $5.40 \mathrm{H}, 6 \times \mathrm{CONCH}_{2} \mathrm{Ar}$, minor rotamer), 3.57-3.31 (m, 5.40H, $6 \times \mathrm{CONCH}_{2} \mathrm{CH}_{2}$, minor rotamer), 3.31$3.03\left(\mathrm{~m}, 6.60 \mathrm{H}, 6 \times \mathrm{CONCH}_{2} \mathrm{CH}_{2}\right.$, major rotamer), $2.74-2.54$ $(\mathrm{m}, 5.40 \mathrm{H}), 2.54-2.35(\mathrm{~m}, 6.60 \mathrm{H}), 1.80-1.31(\mathrm{~m}, 24 \mathrm{H}) \mathrm{ppm}$. ${ }^{13} \mathrm{C}$ NMR $\left(75 \mathrm{MHz}, \mathrm{CDCl}_{3}\right): \delta=172.5,172.2,171.8\left(7 \mathrm{C}_{\mathrm{q}}\right)$, $142.0,141.4,138.9,138.4,135.8,135.4,135.1\left(19 \mathrm{C}_{\mathrm{q}}\right), 130.5$ $(2 \mathrm{CH}), 129.7,128.5,128.3,128.0,127.2,127.0,126.8,126.4$, $125.8(57 \mathrm{CH}), 52.2\left(\mathrm{br}, 2.70 \mathrm{CH}_{2}, 6 \times \mathrm{CONCH}_{2} \mathrm{Ar}\right.$, minor rotamer), 48.3 (br, $3.30 \mathrm{CH}_{2}, 6 \times \mathrm{CONCH}_{2} \mathrm{CH}_{2}$, major rotamer), 47.2 (br, $3.30 \mathrm{CH}_{2}, 6 \times \mathrm{CONCH}_{2} \mathrm{Ar}$, major rotamer), $44.6\left(\mathrm{br}, 2.70 \mathrm{CH}_{2}\right.$, $6 \times \mathrm{CONCH}_{2} \mathrm{CH}_{2}$, minor rotamer), 35.4, $35.0\left(\mathrm{CH}_{2}\right), 28.6,27.9$, 27.5, 26.3 $\left(12 \mathrm{CH}_{2}\right)$ ppm. $v_{\max } / \mathrm{cm}^{-1}$ (ATR) $3025,2930,2859,1717$ $(\mathrm{C}=\mathrm{O}), 1632(\mathrm{C}=\mathrm{O}), 1455(\mathrm{CH}), 1423,1410,1308(\mathrm{OH}), 1260$, $1174(\mathrm{CN})$. HRMS (TOF MS ES ${ }^{+}$) calcd for $\mathrm{C}_{115} \mathrm{H}_{121} \mathrm{~N}_{6} \mathrm{O}_{8}[\mathrm{M}+$ $2 \mathrm{H}]^{2+} \mathrm{m} / z$ 857.4657, found 857.4657.

Arylopeptoid hexamer $\boldsymbol{m}$-6c. Colorless foam (84 mg, 39\%, $>99 \%$ purity). $\mathrm{mp}=48-51{ }^{\circ} \mathrm{C} .{ }^{1} \mathrm{H}$ NMR $\left(300 \mathrm{MHz}, \mathrm{CDCl}_{3}\right)$ : $\delta=9.70-9.30($ br s, $1 \mathrm{H}, \mathrm{COOH}), 8.04-7.70(\mathrm{~m}, 2 \mathrm{H}), 7.48-$ $6.94(\mathrm{~m}, 57 \mathrm{H}), 4.83-4.59$ (br s, $6.60 \mathrm{H}, 6 \times \mathrm{CONCH}_{2} \mathrm{Ar}$, major rotamer), $4.59-4.32$ (br s, $5.40 \mathrm{H}, 6 \times \mathrm{CONCH}_{2} \mathrm{Ar}$, minor rotamer), 3.57-3.28 (m, $5.40 \mathrm{H}, 6 \times \mathrm{CONCH}_{2} \mathrm{CH}_{2}$, minor rotamer), 3.28$3.00\left(\mathrm{~m}, 6.60 \mathrm{H}, 6 \times \mathrm{CONCH}_{2} \mathrm{CH}_{2}\right.$, major rotamer), 2.71-2.51 $(\mathrm{m}, 5.40 \mathrm{H}), 2.51-2.33(\mathrm{~m}, 6.60 \mathrm{H}), 1.78-1.22(\mathrm{~m}, 24 \mathrm{H}) \mathrm{ppm}$. ${ }^{13} \mathrm{C}$ NMR $\left(75 \mathrm{MHz}, \mathrm{CDCl}_{3}\right): \delta=172.6,172.2,171.8\left(7 \mathrm{C}_{\mathrm{q}}\right)$, $142.0,141.4,137.6,137.4,137.3,136.4,136.2,135.7\left(19 \mathrm{C}_{\mathrm{q}}\right)$, $129.7,129.0,128.5,128.3,127.7,126.4,126.2,125.8,125.6$ $(59 \mathrm{CH}), 52.2$ (br, $2.70 \mathrm{CH}_{2}, 6 \times \mathrm{CONCH}_{2} \mathrm{Ar}$, minor rotamer), 48.4 (br, $3.30 \mathrm{CH}_{2}, 6 \times \mathrm{CONCH}_{2} \mathrm{CH}_{2}$, major rotamer), 47.4 (br, $3.30 \mathrm{CH}_{2}, 6 \times \mathrm{CONCH}_{2} \mathrm{Ar}$, major rotamer), 44.7 (br, $2.70 \mathrm{CH}_{2}$, $6 \times \mathrm{CONCH}_{2} \mathrm{CH}_{2}$, minor rotamer), 35.4, $35.0\left(6 \mathrm{CH}_{2}\right), 28.5,27.9$, 27.6, $26.4\left(12 \mathrm{CH}_{2}\right)$ ppm. $v_{\max } / \mathrm{cm}^{-1}$ (ATR) $3025,2933,2860,1714$ $(\mathrm{C}=\mathrm{O}), 1630(\mathrm{C}=\mathrm{O}), 1453(\mathrm{CH}), 1416,1301(\mathrm{OH}), 1195,1171$ (CN). HRMS (TOF MS ES ${ }^{+}$) calcd for $\mathrm{C}_{115} \mathrm{H}_{121} \mathrm{~N}_{6} \mathrm{O}_{8}[\mathrm{M}+2 \mathrm{H}]^{2+}$ $\mathrm{m} / \mathrm{z}$ 857.4657, found 857.4650 .

Arylopeptoid hexamer $\boldsymbol{p}$-6d. Colorless foam isolated as the corresponding TFA-salt (164 mg, 58\%, >99\% purity). $\mathrm{mp}=62$ $65{ }^{\circ} \mathrm{C} .{ }^{1} \mathrm{H}$ NMR $\left(300 \mathrm{MHz}, \mathrm{MeCN}-d_{3}\right): \delta=11.30-9.40(\mathrm{br} \mathrm{s}$, $7 \mathrm{H}, 6 \times \mathrm{CF}_{3} \mathrm{COOH}$ and $\left.\mathrm{COOH}\right), 8.00-7.91(\mathrm{~m}, 2 \mathrm{H}), 7.64-7.08(\mathrm{~m}$, $27 \mathrm{H}), 4.83-4.44\left(\mathrm{~m}, 12 \mathrm{H}, 6 \times \mathrm{CONCH}_{2} \mathrm{Ar}\right), 4.10-3.89(\mathrm{~m}, 12 \mathrm{H})$, 3.88-3.66 (m, 24H), 3.66-3.45 (m, $12 \mathrm{H}), 3.40-3.21(\mathrm{~m}, 12 \mathrm{H}$, $\left.6 \times \mathrm{CONCH}_{2} \mathrm{CH}_{2}\right), 3.20-2.91(\mathrm{~m}, 12 \mathrm{H}) \mathrm{ppm} .{ }^{13} \mathrm{C} \mathrm{NMR}(75 \mathrm{MHz}$, $\left.\mathrm{MeCN}-d_{3}\right): \delta=174.8,174.2\left(6 \mathrm{C}_{\mathrm{q}}\right), 167.9\left(\mathrm{C}_{\mathrm{q}}\right), 161.0(\mathrm{q}, J=36.1 \mathrm{~Hz}$, $\left.6 \mathrm{C}_{\mathrm{q}}, 6 \times \mathrm{CF}_{3} \mathrm{COOH}\right), 142.6,139.5,136.0,135.5,130.9\left(13 \mathrm{C}_{\mathrm{q}}\right), 131.0$
(2CH), 131.2, 129.4, 128.4, $128.0(27 \mathrm{CH}), 116.0$ (q, $J=290.9 \mathrm{~Hz}$, $\left.6 \mathrm{C}_{\mathrm{q}}, 6 \times \mathrm{CF}_{3} \mathrm{COOH}\right), 64.7\left(12 \mathrm{CH}_{2}\right), 55.8\left(6 \mathrm{CH}_{2}, 6 \times \mathrm{CONCH}_{2} \mathrm{CH}_{2}\right)$, $53.7\left(6 \mathrm{CH}_{2}, 6 \times \mathrm{CONCH}_{2} \mathrm{Ar}\right), 53.1\left(12 \mathrm{CH}_{2}\right), 41.3\left(6 \mathrm{CH}_{2}\right) \mathrm{ppm}$. $v_{\max } / \mathrm{cm}^{-1}$ (ATR) 3001, 2930, 2858, $1669(\mathrm{C}=\mathrm{O}), 1635(\mathrm{C}=\mathrm{O})$, $1458(\mathrm{CH}), 1418,1179(\mathrm{CN}), 1129(\mathrm{CO}), 1088(\mathrm{CN}), 938,798$. HRMS (TOF MS ES ${ }^{+}$) calcd for $\mathrm{C}_{91} \mathrm{H}_{118} \mathrm{~N}_{12} \mathrm{O}_{14}[\mathrm{M}+4 \mathrm{H}]^{4+} \mathrm{m} / z$ 400.7217, found 400.7208 .

Arylopeptoid hexamer $\boldsymbol{m}$-6d. Colorless foam isolated as the corresponding TFA-salt (119 mg, 41\%, >99\% purity). $\mathrm{mp}=61-$ $64{ }^{\circ} \mathrm{C} .{ }^{1} \mathrm{H}$ NMR $\left(300 \mathrm{MHz}, \mathrm{MeCN}-d_{3}\right): \delta=7.94-7.75(\mathrm{~m}, 2 \mathrm{H})$, 7.54-6.50 (m, $34 \mathrm{H}, \mathrm{Ar}-\mathrm{H}, 6 \times \mathrm{CF}_{3} \mathrm{COOH}$ and $\left.\mathrm{COOH}\right), 4.80-4.39$ $\left(\mathrm{m}, 12 \mathrm{H}, 6 \times \mathrm{CONCH}_{2} \mathrm{Ar}\right), 4.12-3.87(\mathrm{~m}, 12 \mathrm{H}), 3.87-3.39(\mathrm{~m}$, $36 \mathrm{H}), 3.39-3.16\left(\mathrm{~m}, 12 \mathrm{H}, 6 \times \mathrm{CONCH}_{2} \mathrm{CH}_{2}\right), 3.16-2.92(\mathrm{~m}, 12 \mathrm{H})$ ppm. ${ }^{13} \mathrm{CNMR}\left(75 \mathrm{MHz}, \mathrm{MeCN}-d_{3}\right): \delta=174.6,174.4,174.2,174.2$ $\left(6 \mathrm{C}_{\mathrm{q}}\right), 168.0\left(\mathrm{C}_{\mathrm{q}}\right), 160.8\left(\mathrm{q}, J=36.4 \mathrm{~Hz}, 6 \mathrm{C}_{\mathrm{q}}, 6 \times \mathrm{CF}_{3} \mathrm{COOH}\right), 137.7$, 137.6, 136.6, 136.5, 136.4, 135.6, $132.2\left(13 \mathrm{C}_{\mathrm{q}}\right), 132.7,131.4,130.4$, 130.3, 130.2, 129.9, 129.8, 129.4, 128.6, 127.9, 127.5, 127.2, 125.4, $125.3,124.8(27 \mathrm{CH}), 117.1$ (q, $\left.J=290.3 \mathrm{~Hz}, 6 \mathrm{C}_{\mathrm{q}}, 6 \times \mathrm{CF}_{3} \mathrm{COOH}\right)$, 64.7, 64.3 $\left(12 \mathrm{CH}_{2}\right), 56.2,56.1,55.9,55.6\left(6 \mathrm{CH}_{2}, 6 \times \mathrm{CONCH}_{2} \mathrm{CH}_{2}\right)$, $53.7\left(6 \mathrm{CH}_{2}, 6 \times \mathrm{CONCH}_{2} \mathrm{Ar}\right), 53.2\left(12 \mathrm{CH}_{2}\right), 41.5,41.0,40.8\left(6 \mathrm{CH}_{2}\right)$ ppm. $v_{\max } / \mathrm{cm}^{-1}$ (ATR) 3013, $1671(\mathrm{C}=\mathrm{O}), 1633(\mathrm{C}=\mathrm{O}), 1463$ $(\mathrm{CH}), 1417,1269(\mathrm{OH}), 1184(\mathrm{CN}), 1138(\mathrm{CO}), 1088(\mathrm{CN}), 986$, 1798. HRMS (TOF MS ES ${ }^{+}$) calcd for $\mathrm{C}_{91} \mathrm{H}_{118} \mathrm{~N}_{12} \mathrm{O}_{14}[\mathrm{M}+4 \mathrm{H}]^{4+}$ $\mathrm{m} / \mathrm{z} 400.7217$, found 400.7217 .

Arylopeptoid hexamer $\boldsymbol{p}$-6e. Pale yellowish foam isolated as the corresponding TFA-salt (58 $\mathrm{mg}, 21 \%,>99 \%$ purity). $\mathrm{mp}=$ $60-63{ }^{\circ} \mathrm{C} .{ }^{1} \mathrm{H}$ NMR $\left(300 \mathrm{MHz}, \mathrm{MeCN}-d_{3}\right): \delta=8.80-8.63(\mathrm{~m}$, $6 \mathrm{H}), 8.63-8.54(\mathrm{~m}, 6 \mathrm{H}), 8.51-8.39\left(\mathrm{br} \mathrm{s}, 7 \mathrm{H}, 6 \times \mathrm{CF}_{3} \mathrm{COOH}\right.$ and $\mathrm{COOH}), 8.36-8.24(\mathrm{~m}, 6 \mathrm{H}), 7.92-7.74(\mathrm{~m}, 8 \mathrm{H}), 7.47-7.07(\mathrm{~m}$, $27 \mathrm{H}), 4.84-4.65$ and $4.65-4.44\left(2 \times b r\right.$ s, $2 \times 12 \mathrm{H}, 6 \times \mathrm{CONCH}_{2} \mathrm{Ar}$ and $\left.6 \times \mathrm{CONCH}_{2} \mathrm{Pyr}\right) \mathrm{ppm} .{ }^{13} \mathrm{C} \mathrm{NMR}\left(75 \mathrm{MHz}, \mathrm{MeCN}-d_{3}\right): \delta=$ $173.3,172.9\left(6 \mathrm{C}_{\mathrm{q}}\right), 167.7\left(\mathrm{C}_{\mathrm{q}}\right), 161.3\left(\mathrm{q}, J=36.0 \mathrm{~Hz}, 6 \mathrm{C}_{\mathrm{q}}\right.$, $\left.6 \times \mathrm{CF}_{3} \mathrm{COOH}\right), 146.1(6 \mathrm{CH}), 142.3(6 \mathrm{CH}), 141.6(6 \mathrm{CH}), 139.4$, $138.9,136.4,135.8\left(19 \mathrm{C}_{\mathrm{q}}\right), 130.9(2 \mathrm{CH}), 129.5,128.6,128.1$, $127.8,127.6(27 \mathrm{CH}), 127.7(6 \mathrm{CH}), 117.3\left(\mathrm{q}, J=290.9 \mathrm{~Hz}, 6 \mathrm{C}_{\mathrm{q}}\right.$, $\left.6 \times \mathrm{CF}_{3} \mathrm{COOH}\right), 53.9$ and $47.1\left(2 \times 6 \mathrm{CH}_{2}, 6 \times \mathrm{CONCH}_{2} \mathrm{Ar}\right.$ and $6 \times \mathrm{CONCH}_{2} \mathrm{Pyr}$ ) ppm. $v_{\max } / \mathrm{cm}^{-1}$ (ATR) $3060,3028,1675(\mathrm{C}=\mathrm{O})$, $1634(\mathrm{C}=\mathrm{O}), 1458(\mathrm{CH}), 1410,1177(\mathrm{CN}), 1135(\mathrm{CN}), 995,796$. HRMS (TOF MS ES ${ }^{+}$) calcd for $\mathrm{C}_{91} \mathrm{H}_{81} \mathrm{~N}_{12} \mathrm{O}_{8}[\mathrm{M}+3 \mathrm{H}]^{3+} \mathrm{m} / \mathrm{z}$ 489.8761 , found 489.8763 .

Arylopeptoid hexamer $\boldsymbol{p}$-7a. Pale rose foam $(77 \mathrm{mg}, 55 \%$, $>99 \%$ purity). $\mathrm{mp}=229-232{ }^{\circ} \mathrm{C} .{ }^{1} \mathrm{H}$ NMR $\left(300 \mathrm{MHz}, \mathrm{CDCl}_{3}\right)$ : $\delta=7.82-7.65(\mathrm{~m}, 2 \mathrm{H}), 7.55-6.92(\mathrm{~m}, 27 \mathrm{H}), 6.84-6.16(\mathrm{~m}, 2 \mathrm{H}$, $\mathrm{CONH}_{2}$ ), 4.82-4.37 (br s, $12 \mathrm{H}, 6 \times \mathrm{CONCH}_{2} \mathrm{Ar}$ ), 4.34-4.02 (br $\left.\mathrm{m}, 6 \mathrm{H}, 6 \times \mathrm{CONC} H\left(\mathrm{CH}_{3}\right)_{2}\right), 1.42-0.92(\mathrm{~m}, 36 \mathrm{H}) \mathrm{ppm} .{ }^{13} \mathrm{C} \mathrm{NMR}$ $\left(75 \mathrm{MHz}, \mathrm{CDCl}_{3}\right): \delta=172.6,172.5,170.1\left(7 \mathrm{C}_{\mathrm{q}}\right), 140.8,136.7$, $135.1,131.3\left(13 \mathrm{C}_{\mathrm{q}}\right), 129.6,128.7,127.9,127.1,126.5,126.2$ $(29 \mathrm{CH}), 51.0\left(\mathrm{br}, 6 \mathrm{CH}, 6 \times \mathrm{CONCH}\left(\mathrm{CH}_{3}\right)_{2}\right), 43.5\left(\mathrm{br}, 6 \mathrm{CH}_{2}\right.$, $\left.6 \times \mathrm{CONCH}_{2} \mathrm{Ar}\right), 21.4\left(12 \mathrm{CH}_{3}\right) \mathrm{ppm} . v_{\max } / \mathrm{cm}^{-1}$ (ATR) 2969, 2929, $1674(\mathrm{C}=\mathrm{O}), 1628(\mathrm{C}=\mathrm{O}), 1437(\mathrm{CH}), 1405,1338,1174$ (CN), 1054, 842. HRMS (TOF MS ES ${ }^{+}$calcd for $\mathrm{C}_{73} \mathrm{H}_{86} \mathrm{~N}_{7} \mathrm{O}_{7}$ $[\mathrm{M}+2 \mathrm{H}]^{2+} \mathrm{m} / \mathrm{z} 586.8328$, found 586.8336 .

Arylopeptoid hexamer $\boldsymbol{m}$-7a. Pale rose foam $(82 \mathrm{mg}, 58 \%$, $>99 \%) . \mathrm{mp}=70-73{ }^{\circ} \mathrm{C} .{ }^{1} \mathrm{H}$ NMR $\left(300 \mathrm{MHz}, \mathrm{CDCl}_{3}\right): \delta=7.93-$ $7.61(\mathrm{~m}, 2 \mathrm{H}), 7.59-6.90(\mathrm{~m}, 28 \mathrm{H}, \mathrm{Ar}-H$ and $\mathrm{CON} H \mathrm{H}), 6.70-6.47$ (br s, $1 \mathrm{H}, \mathrm{CONH} H), 4.82-4.34\left(\mathrm{br} \mathrm{s}, 12 \mathrm{H}, 6 \times \mathrm{CONCH}_{2} \mathrm{Ar}\right), 4.30$ $3.92\left(\mathrm{br} \mathrm{m}, 6 \mathrm{H}, 6 \times \mathrm{CONCH}\left(\mathrm{CH}_{3}\right)_{2}\right), 1.42-0.92(\mathrm{~m}, 36 \mathrm{H}) \mathrm{ppm} .{ }^{13} \mathrm{C}$ 
NMR (75 MHz, $\left.\mathrm{CDCl}_{3}\right): \delta=172.8,172.7,170.7\left(7 \mathrm{C}_{\mathrm{q}}\right), 139.6$, 136.4, $132.7\left(13 \mathrm{C}_{\mathrm{q}}\right), 130.9,129.5,128.8,128.7,128.6,128.1,126.2$, $126.1,124.8,124.6(29 \mathrm{CH}), 51.0\left(\mathrm{br}, 6 \mathrm{CH}, 6 \times \mathrm{CONCH}\left(\mathrm{CH}_{3}\right)_{2}\right)$, 43.5 (br, $\left.6 \mathrm{CH}_{2}, 6 \times \mathrm{CONCH}_{2} \mathrm{Ar}\right), 21.3\left(12 \mathrm{CH}_{3}\right) \mathrm{ppm} . v_{\max } / \mathrm{cm}^{-1}$ (ATR) 2973, 2932, $1678(\mathrm{C}=\mathrm{O}), 1624(\mathrm{C}=\mathrm{O}), 1448(\mathrm{CH}), 1410$, 1338, $1175(\mathrm{CN}), 1061,793$. HRMS (TOF MS ES ${ }^{+}$) calcd for $\mathrm{C}_{73} \mathrm{H}_{86} \mathrm{~N}_{7} \mathrm{O}_{7}[\mathrm{M}+2 \mathrm{H}]^{2+} \mathrm{m} / z$ 586.8328, found 586.8329 .

Arylopeptoid hexamer $\boldsymbol{p}$-7b. Pale rose foam $(70 \mathrm{mg}, 54 \%$, $>99 \%$ purity). $\mathrm{mp}=67-70{ }^{\circ} \mathrm{C} .{ }^{1} \mathrm{H}$ NMR $\left(300 \mathrm{MHz}, \mathrm{CDCl}_{3}\right)$ : $\delta=7.86-7.79(\mathrm{~m}, 2 \mathrm{H}), 7.51-7.09(\mathrm{~m}, 27 \mathrm{H}), 6.95-6.32(\mathrm{~m}, 2 \mathrm{H}$, $\mathrm{CONH}_{2}$ ), 4.90-4.65 (br s, 7.20H, $6 \times \mathrm{CONCH}_{2} \mathrm{Ar}$, major rotamer), 4.65-4.41 (br s, $4.80 \mathrm{H}, 6 \times \mathrm{CONCH}_{2} \mathrm{Ar}$, minor rotamer), 3.65$3.38\left(\mathrm{~m}, 4.80 \mathrm{H}, 6 \times \mathrm{CONCH}_{2} \mathrm{CH}_{3}\right.$, minor rotamer), 3.38-3.11 (m, $7.20 \mathrm{H}, 6 \times \mathrm{CONCH}_{2} \mathrm{CH}_{3}$, major rotamer), $1.33-0.95(\mathrm{~m}, 18 \mathrm{H})$ ppm. ${ }^{13} \mathrm{C}$ NMR $\left(75 \mathrm{MHz}, \mathrm{CDCl}_{3}\right): \delta=172.4,171.9,170.0\left(7 \mathrm{C}_{\mathrm{q}}\right)$, $139.0,138.6,135.9,135.2,131.8\left(13 \mathrm{C}_{\mathrm{q}}\right), 129.7,128.5,128.1$, 126.9, $126.3(29 \mathrm{CH}), 51.9$ (br, $2.40 \mathrm{CH}_{2}, 6 \times \mathrm{CONCH}_{2} \mathrm{Ar}$, minor rotamer), 47.0 (br, $3.60 \mathrm{CH}_{2}, 6 \times \mathrm{CONCH}_{2} \mathrm{Ar}$, major rotamer), 43.3 (br, $3.60 \mathrm{CH}_{2}, 6 \times \mathrm{CONCH}_{2} \mathrm{CH}_{3}$, major rotamer), 40.2 (br, $2.40 \mathrm{CH}_{2}, 6 \times \mathrm{CONCH}_{2} \mathrm{CH}_{3}$, minor rotamer), 13.7, $12.1\left(6 \mathrm{CH}_{3}\right)$ ppm. $v_{\max } / \mathrm{cm}^{-1}$ (ATR) $2973,1675(\mathrm{C}=\mathrm{O}), 1627(\mathrm{C}=\mathrm{O}), 1430$ (CH), 1410, 1286, $1176(\mathrm{CN}), 1095,1074,980$. HRMS (TOF MS ES ${ }^{+}$) calcd for $\mathrm{C}_{67} \mathrm{H}_{75} \mathrm{~N}_{7} \mathrm{O}_{7}[\mathrm{M}+2 \mathrm{H}]^{2+} \mathrm{m} / z$ 544.7859, found 544.7861 .

Arylopeptoid hexamer $\boldsymbol{p}$-7c. Colorless foam $(95 \mathrm{mg}, 46 \%$, $>99 \%$ purity). $\mathrm{mp}=52-55{ }^{\circ} \mathrm{C} .{ }^{1} \mathrm{H}$ NMR $\left(300 \mathrm{MHz}, \mathrm{CDCl}_{3}\right)$ : $\delta=7.82-7.72(\mathrm{~m}, 2 \mathrm{H}), 7.46-6.97(\mathrm{~m}, 57 \mathrm{H}), 6.82-6.20(\mathrm{~m}$, $\left.2 \mathrm{H}, \mathrm{CONH} \mathrm{H}_{2}\right), 4.84-4.60$ (br s, $6.60 \mathrm{H}, 6 \times \mathrm{CONCH}_{2} \mathrm{Ar}$, major rotamer), $4.60-4.36$ (br s, $5.40 \mathrm{H}, 6 \times \mathrm{CONCH}_{2} \mathrm{Ar}$, minor rotamer), 3.57-3.31 (m, 5.40H, $6 \times \mathrm{CONCH}_{2} \mathrm{CH}_{2}$, minor rotamer), 3.31$3.05\left(\mathrm{~m}, 6.60 \mathrm{H}, 6 \times \mathrm{CONCH}_{2} \mathrm{CH}_{2}\right.$, major rotamer), 2.74-2.54 $(\mathrm{m}, 5.40 \mathrm{H}), 2.54-2.35(\mathrm{~m}, 6.60 \mathrm{H}), 1.80-1.24(\mathrm{~m}, 24 \mathrm{H}) \mathrm{ppm}$. ${ }^{13} \mathrm{C}$ NMR $\left(75 \mathrm{MHz}, \mathrm{CDCl}_{3}\right): \delta=172.4,172.1,171.7\left(7 \mathrm{C}_{\mathrm{q}}\right)$, $142.0,141.4,138.9,138.4,136.0,135.4,135.2\left(19 \mathrm{C}_{\mathrm{q}}\right), 129.6$, $128.5,128.3,128.1,128.0,127.1,127.0,126.8,126.4,125.8$ $(59 \mathrm{CH}), 52.2$ (br, $2.70 \mathrm{CH}_{2}, 6 \times \mathrm{CONCH}_{2} \mathrm{Ar}$, minor rotamer), 48.3 (br, $3.30 \mathrm{CH}_{2}, 6 \times \mathrm{CONCH}_{2} \mathrm{CH}_{2}$, major rotamer), 47.2 (br, $3.30 \mathrm{CH}_{2}, 6 \times \mathrm{CONCH}_{2} \mathrm{Ar}$, major rotamer), $44.6\left(\mathrm{br}, 2.70 \mathrm{CH}_{2}\right.$, $6 \times \mathrm{CONCH}_{2} \mathrm{CH}_{2}$, minor rotamer), 35.4, $35.0\left(6 \mathrm{CH}_{2}\right)$, 28.6, 27.9, 27.5, $26.3\left(12 \mathrm{CH}_{2}\right)$ ppm. $v_{\max } / \mathrm{cm}^{-1}(\mathrm{ATR}) 2929,1675(\mathrm{C}=\mathrm{O})$, $1629(\mathrm{C}=\mathrm{O}), 1453(\mathrm{CH}), 1410,1309,1173(\mathrm{CN})$. HRMS (TOF MS ES ${ }^{+}$) calcd for $\mathrm{C}_{115} \mathrm{H}_{123} \mathrm{~N}_{7} \mathrm{O}_{7}[\mathrm{M}+2 \mathrm{H}]^{2+} m / z$ 856.9737, found 856.9747 .

Arylopeptoid hexamer $\boldsymbol{m}$-7c. Colorless foam (109 mg, 53\%, $>99 \%$ purity). $\mathrm{mp}=54-57{ }^{\circ} \mathrm{C} .{ }^{1} \mathrm{H}$ NMR $\left(300 \mathrm{MHz}, \mathrm{CDCl}_{3}\right)$ : $\delta=7.84-7.56(\mathrm{~m}, 2 \mathrm{H}), 7.56-6.92(\mathrm{~m}, 57 \mathrm{H}), 6.22-5.54(\mathrm{~m}$, $2 \mathrm{H}, \mathrm{CONH}_{2}$ ), 4.81-4.56 (br s, $6.90 \mathrm{H}, 6 \times \mathrm{CONCH}_{2} \mathrm{Ar}$, major rotamer), $4.56-4.32$ (br s, $5.10 \mathrm{H}, 6 \times \mathrm{CONCH}_{2} \mathrm{Ar}$, minor rotamer), 3.56-3.29 (m, 5.10H, $6 \times \mathrm{CONCH}_{2} \mathrm{CH}_{2}$, minor rotamer), 3.29$3.03\left(\mathrm{~m}, 6.90 \mathrm{H}, 6 \times \mathrm{CONCH}_{2} \mathrm{CH}_{2}\right.$, major rotamer), 2.71-2.54 $(\mathrm{m}, 5.10 \mathrm{H}), 2.54-2.33(\mathrm{~m}, 6.90 \mathrm{H}), 1.75-1.23(\mathrm{~m}, 24 \mathrm{H}) \mathrm{ppm}$. ${ }^{13} \mathrm{C}$ NMR $\left(75 \mathrm{MHz}, \mathrm{CDCl}_{3}\right): \delta=172.3,172.0,171.6,169.6$ $\left(7 \mathrm{C}_{\mathrm{q}}\right), 142.0,141.4,137.8,137.5,136.8,136.6,136.1\left(19 \mathrm{C}_{\mathrm{q}}\right)$, $129.6,129.0,129.0,128.5,128.3,126.5,126.2,125.8,125.5$ $(59 \mathrm{CH}), 52.2$ (br, $2.55 \mathrm{CH}_{2}, 6 \times \mathrm{CONCH}_{2} \mathrm{Ar}$, minor rotamer), 48.4 (br, $3.45 \mathrm{CH}_{2}, 6 \times \mathrm{CONCH}_{2} \mathrm{CH}_{2}$, major rotamer), 47.4 (br, $3.45 \mathrm{CH}_{2}, 6 \times \mathrm{CONCH}_{2} \mathrm{Ar}$, major rotamer), 44.6 (br, $2.55 \mathrm{CH}_{2}$,
$6 \times \mathrm{CONCH}_{2} \mathrm{CH}_{2}$, minor rotamer), 35.4, $35.0\left(6 \mathrm{CH}_{2}\right)$, 28.6, 28.0, 27.7, $26.4\left(12 \mathrm{CH}_{2}\right)$ ppm. $v_{\max } / \mathrm{cm}^{-1}$ (ATR) $3023,2929,2858,1675$ $(\mathrm{C}=\mathrm{O}), 1631(\mathrm{C}=\mathrm{O}), 1453(\mathrm{CH}), 1415,1301,1200,793$. HRMS (TOF MS ES ${ }^{+}$) calcd for $\mathrm{C}_{115} \mathrm{H}_{123} \mathrm{~N}_{7} \mathrm{O}_{7}[\mathrm{M}+2 \mathrm{H}]^{2+} \mathrm{m} / z$ 856.9737, found 856.9743 .

Arylopeptoid hexamer $\boldsymbol{p}-\mathbf{7 d}$. Colorless foam isolated as the corresponding TFA-salt ( $159 \mathrm{mg}, 58 \%,>99 \%$ purity). $\mathrm{mp}=69$ $72{ }^{\circ} \mathrm{C} .{ }^{1} \mathrm{H}$ NMR $\left(300 \mathrm{MHz}, \mathrm{MeCN}-d_{3}\right): \delta=11.50-9.60$ (br s, $\left.6 \mathrm{H}, 6 \times \mathrm{CF}_{3} \mathrm{COOH}\right), 7.85-7.76(\mathrm{~m}, 2 \mathrm{H}), 7.55-7.14(\mathrm{~m}, 27 \mathrm{H}), 7.09-$ $6.25\left(\mathrm{~m}, 2 \mathrm{H}, \mathrm{CONH}_{2}\right), 4.77-4.47\left(\mathrm{~m}, 12 \mathrm{H}, 6 \times \mathrm{CONCH}_{2} \mathrm{Ar}\right), 4.08-$ $3.89(\mathrm{~m}, 12 \mathrm{H}), 3.89-3.65(\mathrm{~m}, 24 \mathrm{H}), 3.65-3.47(\mathrm{~m}, 12 \mathrm{H}), 3.37-3.18$ (m, $\left.12 \mathrm{H}, 6 \times \mathrm{CONCH}_{2} \mathrm{CH}_{2}\right), 3.18-2.94(\mathrm{~m}, 12 \mathrm{H}) \mathrm{ppm} .{ }^{13} \mathrm{C}$ NMR $\left(75 \mathrm{MHz}, \mathrm{MeCN}-d_{3}\right): \delta=174.9,174.4,174.2,169.6\left(7 \mathrm{C}_{\mathrm{q}}\right), 160.8$ (q, $\left.J=36.3 \mathrm{~Hz}, 6 \mathrm{C}_{\mathrm{q}}, 6 \times \mathrm{CF}_{3} \mathrm{COOH}\right), 141.1,139.5,135.5,134.0$ $\left(13 \mathrm{C}_{\mathrm{q}}\right), 131.2,129.4,129.0,128.4,128.0,127.8(29 \mathrm{CH}), 117.2(\mathrm{q}$, $\left.J=290.6 \mathrm{~Hz}, 6 \mathrm{C}_{\mathrm{q}}, 6 \times \mathrm{CF}_{3} \mathrm{COOH}\right), 64.7\left(12 \mathrm{CH}_{2}\right), 55.9\left(6 \mathrm{CH}_{2}\right.$, $\left.6 \times \mathrm{CONCH}_{2} \mathrm{CH}_{2}\right), 53.7\left(6 \mathrm{CH}_{2}, 6 \times \mathrm{CONCH}_{2} \mathrm{Ar}\right), 53.1\left(12 \mathrm{CH}_{2}\right)$, $41.3\left(6 \mathrm{CH}_{2}\right) \mathrm{ppm} . v_{\max } / \mathrm{cm}^{-1}$ (ATR) $2874,1675(\mathrm{C}=\mathrm{O}), 1631$ $(\mathrm{C}=\mathrm{O}), 1466(\mathrm{CH}), 1181(\mathrm{CN}), 1129(\mathrm{CO}), 1088,984,798$. HRMS (TOF MS ES ${ }^{+}$) calcd for $\mathrm{C}_{91} \mathrm{H}_{119} \mathrm{~N}_{13} \mathrm{O}_{13}[\mathrm{M}+4 \mathrm{H}]^{4+} \mathrm{m} / z$ 400.4757, found 400.4759 .

Arylopeptoid hexamer $\boldsymbol{m}$-7d. Colorless foam isolated as the corresponding TFA-salt ( $162 \mathrm{mg}, 59 \%,>99 \%$ purity). $\mathrm{mp}=57-$ $60{ }^{\circ} \mathrm{C} .{ }^{1} \mathrm{H}$ NMR $\left(300 \mathrm{MHz}, \mathrm{MeCN}-d_{3}\right): \delta=8.60-7.80$ (br s, $\left.6 \mathrm{H}, 6 \times \mathrm{CF}_{3} \mathrm{COOH}\right), 7.80-7.65(\mathrm{~m}, 2 \mathrm{H}), 7.55-7.13(\mathrm{~m}, 28 \mathrm{H}, \mathrm{Ar}-$ $H$ and $\mathrm{CON} H \mathrm{H}), 6.60-6.35(\mathrm{br} \mathrm{s}, 1 \mathrm{H}, \mathrm{CONH} H), 4.80-4.39(\mathrm{~m}$, $\left.12 \mathrm{H}, 6 \times \mathrm{CONCH}_{2} \mathrm{Ar}\right), 4.10-3.90(\mathrm{~m}, 12 \mathrm{H}), 3.90-3.37(\mathrm{~m}, 36 \mathrm{H})$, 3.37-3.15 (m, 12H, $\left.6 \times \mathrm{CONCH}_{2} \mathrm{CH}_{2}\right), 3.15-2.92(\mathrm{~m}, 12 \mathrm{H}) \mathrm{ppm}$. ${ }^{13} \mathrm{C}$ NMR $\left(75 \mathrm{MHz}, \mathrm{MeCN}-d_{3}\right): \delta=175.0,174.5,174.1,169.9$ $\left(7 \mathrm{C}_{\mathrm{q}}\right), 160.7$ (q, $\left.J=36.7 \mathrm{~Hz}, 6 \mathrm{C}_{\mathrm{q}}, 6 \times \mathrm{CF}_{3} \mathrm{COOH}\right), 160.5,160.0$, 137.7, 137.5, 136.7, 136.6, 136.5, 135.7, $135.2\left(13 \mathrm{C}_{\mathrm{q}}\right), 131.5,131.4$, $129.4,127.9,127.5,127.4,127.2,125.5,125.2,125.0(27 \mathrm{CH}), 117.1$ (q, $\left.J=290.1 \mathrm{~Hz}, 6 \mathrm{C}_{\mathrm{q}}, 6 \times C \mathrm{~F}_{3} \mathrm{COOH}\right), 64.7\left(12 \mathrm{CH}_{2}\right), 56.0,55.9$, $55.5\left(6 \mathrm{CH}_{2}, 6 \times \mathrm{CONCH}_{2} \mathrm{CH}_{2}\right), 53.7\left(6 \mathrm{CH}_{2}, 6 \times \mathrm{CONCH}_{2} \mathrm{Ar}\right), 53.2$ $\left(12 \mathrm{CH}_{2}\right), 41.5,41.1,41.0\left(6 \mathrm{CH}_{2}\right) \mathrm{ppm} . v_{\max } / \mathrm{cm}^{-1}$ (ATR) 2973,1668 $(\mathrm{C}=\mathrm{O}), 1634(\mathrm{C}=\mathrm{O}), 1464(\mathrm{CH}), 1418,1178(\mathrm{CO}), 1137(\mathrm{CN})$, 1088, 983, 798. HRMS (TOF MS ES ${ }^{+}$) calcd for $\mathrm{C}_{91} \mathrm{H}_{119} \mathrm{~N}_{13} \mathrm{O}_{13}[\mathrm{M}$ $+4 \mathrm{H}]^{4+} \mathrm{m} / \mathrm{z} 400.4757$, found 400.4764 .

Arylopeptoid hexamer $\boldsymbol{p}$-7e. Pale yellowish foam isolated as the corresponding TFA-salt ( $58 \mathrm{mg}, 22 \%,>99 \%$ purity). $\mathrm{mp}=62-$ $65{ }^{\circ} \mathrm{C} .{ }^{1} \mathrm{H}$ NMR $\left(300 \mathrm{MHz}, \mathrm{MeCN}-d_{3}\right): \delta=8.90-8.73(\mathrm{~m}, 6 \mathrm{H})$, 8.73-8.62 (m, 6H), 8.50-8.20 (m, 6H), 7.00-7.81 (m, 8H), 7.60$7.20(\mathrm{~m}, 27 \mathrm{H}), 6.85-6.25\left(\mathrm{~m}, 8 \mathrm{H}, 6 \times \mathrm{CF}_{3} \mathrm{COOH}\right.$ and $\left.\mathrm{CON} H_{2}\right)$, 4.95-4.76 and 4.76-4.54 (2×br s, $2 \times 12 \mathrm{H}, 6 \times \mathrm{CONCH}_{2} \mathrm{Ar}$ and $6 \times \mathrm{CONCH}_{2} \mathrm{Pyr}$ ) ppm. ${ }^{13} \mathrm{C}$ NMR $\left(75 \mathrm{MHz}, \mathrm{MeCN}-d_{3}\right): \delta=173.2$, $172.9,169.4\left(7 \mathrm{C}_{\mathrm{q}}\right), 161.2\left(\mathrm{q}, J=36.2 \mathrm{~Hz}, 6 \mathrm{C}_{\mathrm{q}}, 6 \times \mathrm{CF}_{3} \mathrm{COOH}\right)$, $146.0(6 \mathrm{CH}), 142.4(6 \mathrm{CH}), 141.6(6 \mathrm{CH}), 139.4,138.9,136.4$, $135.8,134.3\left(19 \mathrm{C}_{\mathrm{q}}\right), 130.9,129.5,128.9,128.6,128.3,128.2,127.6$ $(35 \mathrm{CH}), 117.3\left(\mathrm{q}, J=290.7 \mathrm{~Hz}, 6 \mathrm{C}_{\mathrm{q}}, 6 \times \mathrm{CF}_{3} \mathrm{COOH}\right), 54.0$ and 47.0 $\left(2 \times 6 \mathrm{CH}_{2}, 6 \times \mathrm{CONCH}_{2} \mathrm{Ar}\right.$ and $\left.6 \times \mathrm{CONCH}_{2} \mathrm{Pyr}\right) \mathrm{ppm} . v_{\max } / \mathrm{cm}^{-1}$ (ATR) 3086, $1673(\mathrm{C}=\mathrm{O}), 1634(\mathrm{C}=\mathrm{O}), 1461(\mathrm{CH}), 1410,1185$, 1134, 994, 796. HRMS (TOF MS ES+) calcd for $\mathrm{C}_{91} \mathrm{H}_{82} \mathrm{~N}_{13} \mathrm{O}_{7}$ $[\mathrm{M}+3 \mathrm{H}]^{3+} \mathrm{m} / \mathrm{z}$ 489.5481, found 489.5472 .

Arylopeptoid hexamer $\boldsymbol{p}$-7f. Colorless foam isolated as the corresponding TFA-salt (119 mg, 49\%, >99\% purity). $\mathrm{mp}=78$ $81{ }^{\circ} \mathrm{C} .{ }^{1} \mathrm{H}$ NMR $(300 \mathrm{MHz}, \mathrm{MeOD}): \delta=7.98-7.82(\mathrm{~m}, 3 \mathrm{H})$, 7.57-7.12 (m, 26H), 4.90-4.71 (br s, $5.00 \mathrm{H}, 6 \times \mathrm{CONCH}_{2} \mathrm{Ar}$, minor 
rotamer), 4.71-4.48 (br s, $7.00 \mathrm{H}, 6 \times \mathrm{CONCH}_{2} \mathrm{Ar}$, major rotamer), 3.60-3.41 (m, $7.00 \mathrm{H}, 6 \times \mathrm{CONCH}_{2} \mathrm{CH}_{2}$, major rotamer), 3.41$3.22\left(\mathrm{~m}, 5.00 \mathrm{H}, 6 \times \mathrm{CONCH}_{2} \mathrm{CH}_{2}\right.$, minor rotamer), $3.05-2.85(\mathrm{~m}$, $7.00 \mathrm{H}), 2.85-2.65(\mathrm{~m}, 5.00 \mathrm{H}), 1.82-1.30(\mathrm{~m}, 24 \mathrm{H}) \mathrm{ppm} .{ }^{13} \mathrm{C} \mathrm{NMR}$ (75 MHz, MeOD): $\delta=174.7,174.4,174.2,174.1,171.9,171.8$ $\left(7 \mathrm{C}_{\mathrm{q}}\right), 162.3\left(\mathrm{q}, J=35.9 \mathrm{~Hz}, 6 \mathrm{C}_{\mathrm{q}}, 6 \times \mathrm{CF}_{3} \mathrm{COOH}\right), 142.2,140.8$, 140.2, 137.3, 136.7, 136.5, 134.5, 134.2 (13C $\left.\mathrm{C}_{\mathrm{q}}\right), 131.1,129.9,129.3$, $129.1,128.9,128.4,128.2,127.6(29 \mathrm{CH}), 117.9(\mathrm{q}, J=291.4 \mathrm{~Hz}$, $6 \mathrm{C}_{4}, 6 \times \mathrm{CF}_{3} \mathrm{COOH}$ ), 53.5 (br, $3.50 \mathrm{CH}_{2}, 6 \times \mathrm{CONCH}_{2} \mathrm{Ar}$, major rotamer), 50.0 (br, $2.50 \mathrm{CH}_{2}, 6 \times \mathrm{CONCH}_{2} \mathrm{CH}_{2}$, minor rotamer), 48.9 (br, 2.50 $\mathrm{CH}_{2}, 6 \times \mathrm{CONCH}_{2} \mathrm{Ar}$, minor rotamer), 46.0, 45.9, 45.7 (br, $3.50 \mathrm{CH}_{2}, 6 \times \mathrm{CONCH}_{2} \mathrm{CH}_{2}$, major rotamer), 40.4, 40.2 $\left(6 \mathrm{CH}_{2}\right), 26.4,25.9,25.6,25.1\left(12 \mathrm{CH}_{2}\right) \mathrm{ppm} . v_{\max } / \mathrm{cm}^{-1}$ (ATR) 3026, 2938, 2874, $1675(\mathrm{C}=\mathrm{O}), 1609(\mathrm{C}=\mathrm{O}), 1471(\mathrm{CH}), 1429$, 1410, 1200, 1177, 1131, 835, 799. HRMS (TOF MS ES ${ }^{+}$) calcd for $\mathrm{C}_{79} \mathrm{H}_{105} \mathrm{~N}_{13} \mathrm{O}_{7}[\mathrm{M}+2 \mathrm{H}]^{2+} m / z$ 673.9130, found 673.9119.

Arylopeptoid hexamer $\boldsymbol{p}$-7g. Colorless foam $(47 \mathrm{mg}, 31 \%$, $>99 \%$ purity). $\mathrm{mp}=181-184{ }^{\circ} \mathrm{C}$ (decomposition). ${ }^{1} \mathrm{H}$ NMR (300 MHz, MeOD): $\delta=7.92-7.82(\mathrm{~m}, 2 \mathrm{H}), 7.52-7.19(\mathrm{~m}, 27 \mathrm{H})$, 4.90-4.75 (br s, $5.00 \mathrm{H}, 6 \times \mathrm{CONCH}_{2} \mathrm{Ar}$, minor rotamer), 4.714.55 (br s, $7.00 \mathrm{H}, 6 \times \mathrm{CONCH}_{2} \mathrm{Ar}$, major rotamer), 4.21-4.08 (br s, $7.00 \mathrm{H}, 6 \times \mathrm{CONCH}_{2} \mathrm{COOH}$, major rotamer), 4.01-3.87 (br s, $5.00 \mathrm{H}, 6 \times \mathrm{CONCH}_{2} \mathrm{COOH}$, minor rotamer) $\mathrm{ppm} \cdot{ }^{13} \mathrm{C} \mathrm{NMR}$ (75 MHz, MeOD): $\delta=175.0,174.7,174.5,172.1,171.9\left(13 \mathrm{C}_{\mathrm{q}}\right)$, $142.0,141.8,140.3,140.2,136.8,136.6,136.2,136.1,136.0$, $135.9,135.8,134.5,134.3\left(13 \mathrm{C}_{\mathrm{q}}\right), 131.4,131.3,129.9,129.8$, 129.6, 129.5, 129.4, 129.3, 129.2, 128.6, 128.4, 128.3, 128.2, 127.8, $127.6(29 \mathrm{CH}), 55.0\left(\mathrm{br}, 3.50 \mathrm{CH}_{2}, 6 \times \mathrm{CONCH}_{2} \mathrm{Ar}\right.$, major rotamer), $51.6\left(\mathrm{br}, 2.50 \mathrm{CH}_{2}, 6 \times \mathrm{CONCH}_{2} \mathrm{COOH}\right.$, minor rotamer), 50.6 (br, $2.50 \mathrm{CH}_{2}, 6 \times \mathrm{CONCH}_{2} \mathrm{Ar}$, minor rotamer), $48.3\left(\mathrm{br}, 3.50 \mathrm{CH}_{2}\right.$, $6 \times \mathrm{CONCH}_{2} \mathrm{COOH}$, major rotamer) ppm. $v_{\max } / \mathrm{cm}^{-1}$ (ATR) 1730 , 1645, $1634(\mathrm{C}=\mathrm{O}), 1609(\mathrm{C}=\mathrm{O}), 1456(\mathrm{CH}), 1423,1404,1260$, 1199, $1176(\mathrm{CN}), 1006,952,838$. HRMS (TOF MS ES ${ }^{+}$) calcd for $\mathrm{C}_{67} \mathrm{H}_{61} \mathrm{~N}_{7} \mathrm{O}_{19}[\mathrm{M}+2 \mathrm{Na}]^{2+} \mathrm{m} / \mathrm{z} 656.6909$, found 656.6875 .

Arylopeptoid hexamer $\boldsymbol{p}-\mathbf{8}$. Colorless foam isolated as the corresponding TFA-salt ( $99 \mathrm{mg}, 25 \%,>99 \%$ purity). $\mathrm{mp}=80$ $84{ }^{\circ} \mathrm{C} .{ }^{1} \mathrm{H}$ NMR $\left(300 \mathrm{MHz}, \mathrm{MeCN}-d_{3}\right): \delta=7.83-7.70(\mathrm{~m}, 2 \mathrm{H})$, 7.57-6.90 (m, 71H), 5.15-4.28 (m, 30H, $\mathrm{CONH}_{2}, 4 \times \mathrm{CF}_{3} \mathrm{COOH}$ and $\left.12 \times \mathrm{CONCH}_{2} \mathrm{Ar}\right), 4.10-3.87(\mathrm{~m}, 12 \mathrm{H}), 3.87-3.63(\mathrm{~m}, 16 \mathrm{H})$, $3.63-3.46(\mathrm{~m}, 8 \mathrm{H}), 3.45-3.12(\mathrm{~m}, 16 \mathrm{H}), 3.11-2.89(\mathrm{~m}, 8 \mathrm{H}), 2.67-$ $2.24(\mathrm{~m}, 8 \mathrm{H}), 1.69-1.23(\mathrm{~m}, 16 \mathrm{H}), 1.22-0.94(\mathrm{~m}, 24 \mathrm{H}) \mathrm{ppm} .{ }^{13} \mathrm{C}$ NMR (75 MHz, MeCN- $\left.d_{3}\right): \delta=174.8,172.6,172.3,169.7\left(13 \mathrm{C}_{\mathrm{q}}\right)$, $160.5\left(\mathrm{q}, J=37.1 \mathrm{~Hz}, 4 \mathrm{C}_{\mathrm{q}}, 4 \times \mathrm{CF}_{3} \mathrm{COOH}\right), 143.1,142.1,138.3$, $137.8,136.1,134.9,133.5\left(29 \mathrm{C}_{\mathrm{q}}\right), 131.3,129.5,129.2,128.8,128.3$, $128.2,127.8,127.6,127.4,126.6(73 \mathrm{CH}), 117.0(\mathrm{q}, J=289.7 \mathrm{~Hz}$, $\left.4 \mathrm{C}_{\mathrm{q}}, 4 \times C \mathrm{~F}_{3} \mathrm{COOH}\right), 64.8\left(8 \mathrm{CH}_{2}\right), 56.3\left(4 \mathrm{CH}_{2}\right), 54.1\left(4 \mathrm{CH}_{2}\right.$, $4 \times \mathrm{CON}$ [2-morpholinoethyl] $\left.\mathrm{CH}_{2} \mathrm{Ar}\right), 53.2\left(8 \mathrm{CH}_{2}\right), 51.7(4 \mathrm{CH}$, $\left.4 \times \mathrm{CONCH}\left(\mathrm{CH}_{3}\right)_{2}\right), 49.9,46.0\left(4 \mathrm{CH}_{2}\right), 48.5\left(4 \mathrm{CH}_{2}, 4 \times \mathrm{CON}[4-\right.$ phenylbutyl] $\left.\mathrm{CH}_{2} \mathrm{Ar}\right)$, $44.0\left(4 \mathrm{CH}_{2}, 4 \times \mathrm{CON}\left[\right.\right.$ isopropyl] $\left.\mathrm{CH}_{2} \mathrm{Ar}\right)$, $41.7\left(4 \mathrm{CH}_{2}\right), 35.9,35.6\left(4 \mathrm{CH}_{2}\right), 30.3,29.5,28.9,28.7\left(8 \mathrm{CH}_{2}\right)$, $21.2\left(8 \mathrm{CH}_{3}\right)$ ppm. $v_{\max } / \mathrm{cm}^{-1}$ (ATR) $2927,2864,1670(\mathrm{C}=\mathrm{O}), 1625$ $(\mathrm{C}=\mathrm{O}), 1458(\mathrm{CH}), 1410,1364,1311,1266,1173(\mathrm{CO}), 1138(\mathrm{CN})$, 1088, 928. HRMS (TOF MS ES ) calcd for $\mathrm{C}_{179} \mathrm{H}_{211} \mathrm{~N}_{17} \mathrm{O}_{17}[\mathrm{M}+$ $4 \mathrm{H}]^{4+} \mathrm{m} / \mathrm{z}$ 717.6537, found 717.6536.

Arylopeptoid hexamer $\boldsymbol{m}-\mathbf{8}$. Colorless foam isolated as the corresponding TFA-salt ( $108 \mathrm{mg}, 27 \%,>99 \%$ purity). $\mathrm{mp}=73-77^{\circ} \mathrm{C}$. ${ }^{1} \mathrm{H}$ NMR $\left(300 \mathrm{MHz}, \mathrm{MeCN}-d_{3}\right): \delta=7.85-7.63(\mathrm{~m}, 2 \mathrm{H}), 7.55-$ $6.90(\mathrm{~m}, 71 \mathrm{H}), 5.05-4.27\left(\mathrm{~m}, 30 \mathrm{H}, \mathrm{CONH}_{2}, 4 \times \mathrm{CF}_{3} \mathrm{COOH}\right.$ and $\left.12 \times \mathrm{CONCH}_{2} \mathrm{Ar}\right), 4.09-3.83(\mathrm{~m}, 12 \mathrm{H}), 3.83-3.37(\mathrm{~m}, 24 \mathrm{H}), 3.37-$ $3.07(\mathrm{~m}, 16 \mathrm{H}), 3.07-2.87(\mathrm{~m}, 8 \mathrm{H}), 2.65-2.23(\mathrm{~m}, 8 \mathrm{H}), 1.68-1.20$ (m, 16H), $1.20-0.90$ (m, 24H) ppm. ${ }^{13} \mathrm{C}$ NMR $(75 \mathrm{MHz}, \mathrm{MeCN}-$ $\left.d_{3}\right): \delta=174.4,172.7,172.3,169.9\left(13 \mathrm{C}_{\mathrm{q}}\right), 160.5(\mathrm{q}, J=36.8 \mathrm{~Hz}$, $\left.4 \mathrm{C}_{\mathrm{q}}, 4 \times \mathrm{CF}_{3} \mathrm{COOH}\right), 143.0,141.2,139.7,139.0,137.8,137.7,136.4$, $135.0\left(29 \mathrm{C}_{\mathrm{q}}\right), 131.3,130.2,129.8,129.7,129.6,129.5,129.2,128.8$, 127.9, 126.6, 126.4, $125.8(73 \mathrm{CH}), 117.1(\mathrm{q}, J=288.2 \mathrm{~Hz}$, $\left.4 \mathrm{C}_{\mathrm{q}}, 4 \times C \mathrm{~F}_{3} \mathrm{COOH}\right), 64.7\left(8 \mathrm{CH}_{2}\right), 56.2\left(4 \mathrm{CH}_{2}\right), 54.0\left(4 \mathrm{CH}_{2}\right.$, $4 \times \mathrm{CON}$ [2-morpholinoethyl] $\left.\mathrm{CH}_{2} \mathrm{Ar}\right), 53.2\left(8 \mathrm{CH}_{2}\right), 51.8(4 \mathrm{CH}$, $\left.4 \times \mathrm{CONCH}\left(\mathrm{CH}_{3}\right)_{2}\right), 49.9,45.5\left(4 \mathrm{CH}_{2}\right), 48.6\left(4 \mathrm{CH}_{2}, 4 \times \mathrm{CON}[4-\right.$ phenylbutyl] $\left.\mathrm{CH}_{2} \mathrm{Ar}\right)$, $44.0 \quad\left(4 \mathrm{CH}_{2}, 4 \times \mathrm{CON}\left[\right.\right.$ isopropyl] $\left.\mathrm{CH}_{2} \mathrm{Ar}\right)$, $41.6\left(4 \mathrm{CH}_{2}\right), 35.9,35.6\left(4 \mathrm{CH}_{2}\right), 29.6,29.4,28.9,28.8\left(8 \mathrm{CH}_{2}\right)$, $21.4\left(8 \mathrm{CH}_{3}\right) \mathrm{ppm} . v_{\max } / \mathrm{cm}^{-1}(\mathrm{ATR}) 2935,2859,1669(\mathrm{C}=\mathrm{O}), 1622$ $(\mathrm{C}=\mathrm{O}), 1463(\mathrm{CH}), 1414,1343,1306,1269,1179(\mathrm{CO}), 1136(\mathrm{CN})$, 1086, 796. HRMS (TOF MS ES ) calcd for $\mathrm{C}_{179} \mathrm{H}_{211} \mathrm{~N}_{17} \mathrm{O}_{17}[\mathrm{M}+$ $4 \mathrm{H}]^{4+} \mathrm{m} / \mathrm{z} 717.6537$, found 717.6542 .

\section{Acknowledgements}

We gratefully thank the Villum Kann Rasmussen Foundation for a grant to T.H, and the Carlsberg Foundation (grants 2009_01_0745 and 2010_01_0518). We are likewise grateful to Bertrand Légeret (Clermont Université, Laboratoire SEESIB) for mass spectrometric analysis of $\boldsymbol{p}-\mathbf{7 f}$ and $\boldsymbol{p}-\mathbf{7 g}$.

\section{Notes and references}

1 For reviews on aromatic oligoamides, see: (a) I. Saraogi and A. D. Hamilton, Chem. Soc. Rev., 2009, 38, 1726-1743; (b) B. Gong, Acc. Chem. Res., 2008, 41, 1376-1386; (c) Z.-T. Li, J.-L. Hou and C. Li, Acc. Chem. Res., 2008, 41, 1343-1353; (d) Z.-T. Li, J.-L. Hou, C. Li and H.-P. Yi, Chem.-Asian J., 2006, 1, 766-778; (e) I. Huc, Eur. J. Org. Chem., 2004, 17-19.

2 For a review on proteomimetics, see: (a) S. Fletcher and A. D. Hamilton, Curr. Opin. Chem. Biol., 2005, 9, 632-638.

3 (a) I. Saraogi, J. A. Hebda, J. Becerril, L. A. Estroff, A. D. Miranker and A. D. Hamilton, Angew. Chem. Int. Ed., 2010, 49, 736-739; (b) I. Saraogi, C. D. Incarvito and A. D. Hamilton, Angew. Chem., Int. Ed., 2008, 47, 9691-9694; (c) Y. Hamuro, S. J. Geib and A. D. Hamilton, J. Am. Chem. Soc., 1996, 118, 7529-7541.

4 (a) L. Yuan, H. Zeng, K. Yamato, A. R. Sanford, W. Feng, H. S. Atreya, D. K. Sukumaran, T. Szyperski and B. Gong, J. Am. Chem. Soc., 2004, 126, 16528-16537; (b) B. Gong, H. Zeng, J. Zhu, L. Yuan, Y. Han, S. Cheng, M. Furukawa, R. D. Parra, A. Y. Kovalevsky, J. L. Mills, E. Skrzypczak-Jankun, S. Martinovic, R. D. Smith, C. Zheng, T. Szyperski and X. C. Zeng, Proc. Natl. Acad. Sci. U. S. A., 2002, 99, 11583-11588; (c) J. Zhu, R. D. Parra, H. Zeng, E. Skrzypczak-Jankun, X. C. Zeng and B. Gong, J. Am. Chem. Soc., 2000, 122, 4219-4220.

5 (a) H. Seyler, C. Storz, R. Abbel and A. F. M. Kilbinger, Soft Matter, 2009, 5, 2543-2545; (b) H. M. König and A. F. M. Kilbinger, Macromol. Rapid Commun., 2008, 29, 1721-1725; (c) R. Abbel, H. Frey, D. Schollmeyer and A. F. M. Kilbinger, Chem.-Eur. J., 2005, 11, 2170 2176.

6 (a) H.-P. Yi, J. Wu, K.-L. Ding, X.-K. Jiang and Z.-T. Li, J. Org. Chem., 2007, 72, 870-877; (b) H.-P. Yi, C. Li, J.-L. Hou, X.-K. Jiang and Z.-T. Li, Tetrahedron, 2005, 61, 7974-7980.

7 (a) J. P. Plante, T. Burnley, B. Malkova, M. E. Webb, S. L. Warriner, T. A. Edwards and A. J. Wilson, Chem. Commun., 2009, 5091-5093; (b) J. Plante, F. Campbell, B. Malkova, C. Kilner, S. L. Warriner and A. J. Wilson, Org. Biomol. Chem., 2008, 6, 138-146.

8 L. Chabaud, J. Clayden, M. Helliwell, A. Page, J. Raftery and L. Vallverdú, Tetrahedron, 2010, 66, 6936-6957.

9 (a) Y. Yan, B. Qin, C. Ren, X. Chen, Y. K. Yip, R. Ye, D. Zhang, H. Su and H. Zeng, J. Am. Chem. Soc., 2010, 132, 5869-5879; (b) J.-M. Ahn and S.-Y. Han, Tetrahedron Lett., 2007, 48, 3543-3547; (c) F. Lu, S.-W. Chi, D.-H. Kim, K.-H. Han, I. D. Kuntz and R. K. Guy, J. Comb. 
Chem., 2006, 8, 315-325; (d) B. König, U. Papke and M. Rödel, New J. Chem., 2000, 24, 39-45; (e) H. Bredereck and H. von Schuh, Chem. Ber., 1948, 81, 215-221.

10 (a) L. A. Estroff, C. D. Incarvito and A. D. Hamilton, J. Am. Chem. Soc., 2004, 126, 2-3; (b) J. T. Ernst, J. Becerril, H. S. Park, H. Yin and A. D. Hamilton, Angew. Chem., Int. Ed., 2003, 42, 535-539.

11 (a) Q. Gan, F. Li, G. Li, B. Kauffmann, J. Xiang, I. Huc and H. Jiang, Chem. Commun., 2010, 46, 297-299; (b) M. Wolffs, N. Delsuc, D. Veldman, N. V. Ahn, R. M. Williams, S. C. J. Meskers, R. A. J. Janssen, I. Huc and A. P. H. J. Schenning, J. Am. Chem. Soc., 2009, 131, 4819-4829; (c) N. Delsuc, T. Kawanami, J. Lefeuvre, A. Shundo, H. Ihara, M. Takafuji and I. Huc, ChemPhysChem, 2008, 9, 1882-1890; (d) Q. Gan, C. Bao, B. Kauffmann, A. Grélard, J. Xiang, S. Liu, I. Huc and H. Jiang, Angew. Chem., Int. Ed., 2008, 47, 1715-1718; (e) E. R. Gillies, F. Deiss, C. Staedel, J.-M. Schmitter and I. Huc, Angew. Chem., Int. Ed., 2007, 46, 4081-4084; (f) E. R. Gillies, C. Dolain, J.-M. Léger and I. Huc, J. Org. Chem., 2006, 71, 7931-7939; (g) C. Dolain, A. Grélard, M. Laguerre, H. Jiang, V. Maurizot and I. Huc, Chem.Eur. J., 2005, 11, 6135-6144; (h) C. Dolain, H. Jiang, J.-M. Léger, P. Guionneau and I. Huc, J. Am. Chem. Soc., 2005, 127, 12943-12951; (i) H. Jiang, C. Dolain, J.-M. Léger, H. Gornitzka and I. Huc, J. Am. Chem. Soc., 2004, 126, 1034-1035; (j) H. Jiang, J.-M. Léger and I. Huc, J. Am. Chem. Soc., 2003, 125, 3448-3449; (k) H. Jiang, J.-M. Léger, C. Dolain, P. Guionneau and I. Huc, Tetrahedron, 2003, 59, 8365-8374.

12 Y. Ferrand, A. M. Kendale, J. Garric, B. Kauffmann and I. Huc, Angew. Chem., Int. Ed., 2010, 49, 1778-1781.

13 N. Raynal, M.-C. Averlant-Petit, G. Bergé, C. Didierjean, M. Marraud, C. Duru, J. Martinez and M. Amblard, Tetrahedron Lett., 2007, 48, $1787-1790$.

14 M. Akazome, Y. Ishii, T. Nireki and K. Ogura, Tetrahedron Lett., 2008, 49, 4430-4433.

15 N. Delsuc, F. Godde, B. Kauffmann, J.-M. Léger and I. Huc, J. Am. Chem. Soc., 2007, 129, 11348-11349.

16 R. K. Jian, L. K. Tsou and A. D. Hamilton, Tetrahedron Lett., 2009, 50, 2787-2789.

17 A. Tanatani, A. Yokoyama, I. Azumaya, Y. Takakura, C. Mitsui, M. Shiro, M. Uchiyama, A. Muranaka, N. Kobayashi and T. Yokozawa, J. Am. Chem. Soc., 2005, 127, 8553-8561.
18 (a) H. M. König, T. Gorelik, U. Kolb and A. F. M. Kilbinger, $J$. Am. Chem. Soc., 2007, 129, 704-708; (b) H. M. König, R. Abbel, D. Schollmeyer and A. F. M. Kilbinger, Org. Lett., 2006, 8, 1819-1822.

19 (a) F. Campbell, J. P. Plante, T. A. Edwards, S. L. Warriner and A. J. Wilson, Org. Biomol. Chem., 2010, 8, 2344-2351; (b) F. Campbell and A. J. Wilson, Tetrahedron Lett., 2009, 50, 2236-2238; (c) F. Campbell, J. Plante, C. Carruthers, M. J. Hardie, T. J. Prior and A. J. Wilson, Chem. Commun., 2007, 2240-2242.

20 For reviews on peptoids, see: (a) A. S. Culf and R. J. Ouelette, Molecules, 2010, 15, 5282-5335; (b) S. A. Fowler and H. E. Blackwell, Org. Biomol. Chem., 2009, 7, 1508-1524; (c) B. Yoo and K. Kirshenbaum, Curr. Opin. Chem. Biol., 2008, 12, 714-721; (d) J. A. Patch, K. Kirshenbaum, S. L. Seurynck, R. N. Zuckermann, A. E. Barron, Pseudopeptides in Drug Discovery, ed. P. E. Nielsen, Wiley-VCH, Weinheim, Germany, 2004, pp. $1-31$.

21 (a) R. N. Zuckermann, D. A. Goff, S. Ng, K. Spear, B. O. Scott, A. C. Sigmund, R. A. Goldsmith, C. K. Marlowe, Y. Pei, L. Richter, R. Simon, US005877278A, 1999; (b) R. N. Zuckermann, D. A. Goff, S. Ng, K. Spear, B. O. Scott, A. C. Sigmund, R. A. Goldsmith, C. K. Marlowe, Y. Pei, L. Richter, R. Simon, WO9640202A1, 1996; (c) R. N. Zuckermann, J. M. Kerr, S. Kent, W. H. Moos, R. J. Simon, D. A. Goff, WO9406451A1, 1994.

22 We believe that "arylopeptoids" is a more convenient and appropriate term than "extended peptoids" which was first suggested in ref. 23 since the term "arylopeptoid" is directly related to the primary structure of this family of compounds.

23 D. J. Combs and R. S. Lokey, Tetrahedron Lett., 2007, 48, 2679-2682.

24 (a) E. De Santis, T. Hjelmgaard, S. Faure, O. Roy, C. Didierjean, B. D. Alexander, G. Siligardi, R. Hussain, T. Jávorfi, A. A. Edwards and C. Taillefumier, Amino Acids, 2011, 41, 663-672; (b) C. Caumes, T. Hjelmgaard, R. Remuson, S. Faure and C. Taillefumier, Synthesis, 2011, 257-264; (c) T. Hjelmgaard, S. Faure, C. Caumes, E. De Santis, A. Edwards and C. Taillefumier, Org. Lett., 2009, 11, 4100-4103.

25 T. Hjelmgaard, S. Faure, D. Staerk, C. Taillefumier and J. Nielsen, Eur. J. Org. Chem., 2011, 4121-4132.

26 A. El-Faham, R. S. Funosas, R. Prohens and F. Albericio, Chem.-Eur. J., 2009, 15, 9404-9416. 